\title{
ENTRE AS FRONTEIRAS DO MORAR E O DIREITO DE DECIDIR: UMA ETNOGRAFIA DAS FAMÍLIAS REMOVIDAS DA VILA DA PAZ NA CIDADE DE BELO HORIZONTE
}

\section{BETWEEN THE BORDERS OF THE DWELLING AND THE RIGHT TO DECIDE: AN ETHNOGRAPHY OF THE FAMILIES REMOVED FROM VILA DA PAZ IN THE CITY OF BELO HORIZONTE}

\author{
Luana Carola Santos ${ }^{1}$ \\ Claudia Mayorga ${ }^{2}$
}

\begin{abstract}
Resumo
O presente manuscrito objetiva apresentar uma pesquisa de doutoramento, que consiste em uma etnografia sobre famílias moradoras da Vila da Paz em processo de remoção do Anel Rodoviário de Belo Horizonte, para a duplicação do mesmo. Para isso, foi realizada uma pesquisa etnometodológica, a partir da interação com os atores do campo, por meio da etnografia e fotoetnografia. Como resultado notamos que os moradores da Vila da Paz têm anunciado em suas narrativas formas de desobediência (FOUCAULT, 1982) e resistência às formas de morar oferecidas pela Política Habitacional de Belo Horizonte. Essa desobediência traz para a cena do processo de remoção o movimento de negação-criação que visibilizam as teias de significado do morar, no âmbito social, urbano e econômico que são importantes para os moradores que resistem reocupando espaços e fortalecendo os vínculos comunitários construídos. Os moradores também vivem em situação de sofrimento social e violência, visto que há um mal-estar produzido pelo não acesso ao direito à moradia e por processos históricos de exclusão mais amplos. Assim como a Vila da Paz, a cidade é permeada por teias de significados, e suas áreas periféricas são formadas por um circuito de resistência espacial e sociopolítica.
\end{abstract}

Palavras-chave: Vila da Paz; Etnografia, Cidade; Remoção; Desobediência.

\section{Abstract}

The present manuscript aims to present a doctoral research, which consists of an ethnography about families living in the Peace Village in process of removal of the Ring Road of Belo Horizonte, for duplication of the same. For this, an ethnomethodological research was carried out, based on the interaction with the actors of the field, through ethnography and photoetnography. As a result we noticed that the residents of Peace Village have announced in their narratives ways of disobedience (FOUCAULT, 1982) and resistance to the housing offered by the Housing Policy of Belo Horizonte. This disobedience brings to the scene of the removal process the denial-creation movement that makes visible the social, urban, and economic fabrics of living that are important to the residents who resist reoccupying spaces and strengthening the built community bonds. Residents also live in situations of social suffering and violence, as there is a malaise produced by the lack of access to the right to housing and by wider historical processes of exclusion. Like the

\footnotetext{
${ }^{1}$ Professora do Departamento de Educação do Instituto de Ciências Humanas e Sociais (ICHS) da UFOP. Doutoranda em Psicologia Social no Programa de Pós-Graduação da UFMG. E-mail: lupsicologiapucminas@gmail.com

2 Professora do Departamento de Psicologia da Universidade Federal de Minas Gerais e do Programa de Pósgraduação em Psicologia. Doutora em Psicologia Social pela Universidade Complutense de Madri - Espanha (2007). E-mail: mayorga.claudia@gmail.com
} 
Village of Peace, the city is permeated by webs of meanings, and its peripheral areas are formed by a circuit of spatial and socio-political resistance.

Keywords: Vila da Paz; Ethnography; City; Removal; Disobedience. 


\section{INTRODUÇÃO}

O presente trabalho tem como objetivo apresentar uma pesquisa realizada nos estudos de doutorado sobre famílias em processo de remoção do anel rodoviário da cidade de Belo Horizonte, para a execução de um grande empreendimento o qual se trata da duplicação do anel rodoviário que se configura como uma via de acesso que perpassa a cidade, cujo objetivo é amenizar o trafego de carros que passam no centro da cidade.

Para isso foi realizada uma etnografia do cotidiano das famílias moradoras da Vila da Paz no sentido de compreender as formas de ocupação dos moradores da Vila. A inserção no campo de pesquisa começou em agosto de 2013, quando a pesquisadora acompanhou audiências públicas da Justiça Federal junto à população do anel rodoviário em processo de remoção, e terminou em dezembro de 2016. Ao longo desses anos, eventos como audiências, implantação do Programa Judicial de Conciliação para remoção e reassentamento humanizados de famílias do anel rodoviário, obras do DNIT na Vila da Paz e ao longo do BR, remoções forçadas, cotidiano das famílias da Vila da Paz dentre outros eventos foram vivenciados.

O conteúdo de algumas audiências públicas presenciadas em agosto de 2014 estavam entorno da desocupação pelas famílias das vilas do anel rodoviário e da BR381, em função da obra de duplicação dos mesmos. Para isso, representantes da Justiça Federal, da Defensoria Pública da União, do Ministério Público Federal, do Departamento Nacional de infraestrutura e da Caixa Econômica Federal, os quais são executores da remoção, começaram a realizar como instrumento para dar início da desocupação - a realização de audiências de conciliação com as famílias moradoras do anel rodoviário. Vale lembrar que as audiências de conciliação são em um instrumento jurídico, em que partes envolvidas em um conflito tentam estabelecer um acordo, junto de um conciliador. No caso da duplicação do anel rodoviário, as audiências aconteceram com participação das famílias moradoras do anel e Justiça Federal.

Alguns dos argumentos presentes nas audiências de conciliação para a desocupação das famílias foi à necessidade de duplicação do anel para o desenvolvimento econômico da região de Belo Horizonte, o grande número de famílias que habitam ao longo dessa via e os riscos aos quais elas estão submetidas diariamente por estarem próximas às vias de rolamento da rodovia. Aliados a essas justificativas, o discurso sobre a remoção das famílias moradoras do anel foi reiterado ao longo das audiências - outro importante imperativo usado como dispositivo de retirada das famílias do anel consistiu no fato de estarem e situação de vulnerabilidade social e econômica. 
Como afirma ROLNIK (2004) às remoções forçadas ou involuntárias desconsideram de maneira arbitrária e discriminatória as conquistas na luta pelo direito à terra das pessoas que ocupam as terras, ou seja, expulsam os pobres, sem reconhecimento dos seus direitos para se vender também a imagem da cidade, que a autora chama de "cidades de stands globais", aquelas que não tem ocupações à primeira vista. No caso da cidade de Belo Horizonte essa imagem da "cidade limpa" tem sido negociada e utilizada como argumento para práticas remocionistas a todo custo de violação de direitos e arbitrariedades do discurso jurídico e econômico, pois o anel rodoviário é uma via que perpassa toda a cidade, e alvo de muitos interesses políticos.

Durante as audiências, notamos uma grande preocupação das autoridades presentes com a execução da obra para minimizar os acidentes, o congestionamento presente na via potencializando assim sua capacidade operacional (Argumentos também presentes no ato sobre duplicação do anel rodoviário e BR381 publicitado no 13 de setembro de 2014). Vale destacar, que o emprego do termo "remoções involuntárias" e a complexidade que esse processo envolveria era empregado muitas vezes na narrativa dos executores da obra, o que nos revela e anuncia as famílias que não havia outra opção a não ser sair das áreas as quais habitavam. Conforme o Conselho de Direitos Humanos da Organização das Nações Unidas (ONU, 2012) sobre segurança de posse e também Direito à Moradia Digna - que garante proteção contra remoções forçadas, assédio e outras ameaças:

(...) la Relatora Especial subraya que la seguridad de la tenencia debe entenderse como un concepto que engloba, como mínimo: a) la protección jurídica contra el desalojo forzoso, el hostigamiento y otras amenazas; b) el reconocimiento jurídico por las autoridades, pero también por los agentes privados, del derecho a vivir en un lugar seguro en condiciones de paz y dignidad; ese reconocimiento comprende el apoyo de las autoridades y un acceso equitativo todos los servicios públicos y la disponibilidad de estos; c) la justiciabilidad; o, dicho de otro modo, la capacidad de exigir por la vía legal la seguridad de la tenencia; para que ese critério sea verdaderamente efectivo puede ser necesario prestar asistencia jurídica con miras a facilitar el acceso a medidas de recurso eficaces; y d) cualquier otro aspecto que se requiera como medida susceptible de facilitar el disfrute de otros aspectos del derecho a una vivienda adecuada en pie de igualdad con el resto de los ciudadano. (ONU,2012, p. 17).

De acordo com os escritos da Relatoria Especial para Direito à moradia do Conselho de Direitos Humanos da ONU, as remoções forçadas devem ocorrer apenas em circunstâncias excepcionais já que produzem diversos efeitos nas pessoas removidas, já que os despejos, na maioria das vezes são acompanhados pelo uso da violência judicial e policial, o que impossibilita muitas pessoas desalojadas a não ter acesso à moradia e seus meios de sobrevivência. 
O processo de remoção das famílias moradoras do anel rodoviária e BR381 e seu modos operandi é público e está descrito em processo do judiciário sob número 57362.09.2013.4.01.3800. Alguns acordos que constam no processo e também presentes nas narrativas das audiências conciliatórias é atribuição de responsabilidades a cada um dos atores envolvidos. No caso do DNIT ${ }^{3}$ o qual ficou responsável por custear toda a parte técnica da remoção, o que envolve não somente a execução da obra como a realização de cadastros das famílias a serem removidas, trabalho comunitário durante e após a remoção, atendimento a assistência social e trabalho intitulado socioeducativo na vila, dentre outros aspectos que envolvem todo o processo de remoção e reassentamento. O DNIT juntamente com o Programa de Remoção e Reassentamento Humanizado das famílias do anel rodoviário e BR381 ficaram responsáveis por toda a realização da obra.

No ato assinado nas audiências conciliatórias não havia espaço para assinatura dos moradores, e também não havia espaços de participação para os mesmos. Geralmente as falas dos moradores aconteciam no início da audiência - e logo depois as decisões referentes ao processo de remoção eram repassadas a eles. No final da audiência, a juíza responsável pelo processo se colocava a disposição para conversar com aqueles que tinham dúvidas.

O que observamos nessas audiências e nas conversas com os moradores após as audiências, é que não há espaços para participação e sim uma desconstituição dos processos e fóruns participativos. Em nenhum momento foi perguntado às famílias sobre seus aspectos culturais, sobre suas atividades produtivas e relações sociais, o que aponta para uma verticalização muito recorrente nos processos de remoção. Todavia, outras formas de questionar o processo de remoção emergiram dos moradores, por meio da participação em coletivos de moradores, como o Conjunto de Moradores do Anel Rodoviário (CMAR), as associações comunitárias e as manifestações realizadas na Justiça Federal para saber sobre os encaminhamentos do processo e suas formas de intervenção na realidade da Vila da Paz.

Os moradores têm buscado meios, de forma coletiva, de (re) existir. Segundo eles, ao saírem das audiências relatavam que sua expectativa era poder contar um pouco sobre suas histórias de lutas e buscar assim alternativas de (re) construção, já que o adjetivo conciliação estava presente no substantivo audiência. Entretanto, quando falamos de Direito à Moradia, o termo conciliação traz um tom pejorativo diante de todo o histórico de luta e resistência consolidado

\footnotetext{
${ }^{3}$ Ver reportagem: http://www.dnit.gov.br/noticias/diretor-geral-acompanha-cadastramento-de-familias-noanel-rodoviario-de-bh que aborda uma das intervenções realizadas pelo DNIT juntamente com o Programa Judicial de Conciliação para Remoção e Reassentamento Humanizado de Famílias do Anel Rodoviário
} 
desde 1970 como a emergência de movimentos sociais que já buscavam a reforma urbana. (ROLNIK, 1994)

Etnografamos assim, nas audiências a presença de uma verticalização no processo de remoção, e também uma tentativa de silenciamento dos moradores frente ao que já havia sido decidido, já que se trata dos direcionamentos da Política Urbana de Belo Horizonte, que desde sua criação já intervém nas ocupações de maneira a removê-las, atualizando a lógica higieniza de planejamento urbano. Essa tentativa de silenciamento, e também de chamar de conciliação, o que já está decidido juridicamente nos remete aos escritos de FOUCAULT (1982) sobre a utilização do direito para criação de verdades. Como relata o autor:

O direito deve ser visto como um procedimento de sujeição, que ele desencadeia, e não como uma legitimidade a ser estabelecida. Para mim, o problema é evitar a questão da soberania e da obediência dos indivíduos que Ihe são submetidos e fazer aparecer em seu lugar o problema da dominação e da sujeição. (p.182)

Podemos dizer então que a realidade do Direito, muitas vezes, pode ser opressora, baseada nas relações de poder que geram mais poder, sendo assim devemos deixar aquele véu de fantasia insculpido na legislação, como afirma o autor. Devemos parar de olhar o dever-ser legal que se refere a uma realidade posta a qualquer custo e não há espaço de questionamento da mesma. Durante os estudos etnográficos os moradores se perguntam a todo tempo sobre o discurso da ilegalidade presente nas terras que ocupam como justificativa para seu despejo forçado. Neste sentido, a partir da análise das audiências conciliatórias e das perguntas que balançam o discurso da verdade jurídica presente nas narrativas dos moradores é que a pergunta de pesquisa surge: Quando é que os moradores vão falar? E os moradores podem falar? Será mesmo que Direito à Moradia deve ser tratado em audiência conciliatória? Conciliar o que? Direitos fundamentais negados? (Fragmentos etnográficos do caderno de campo sobre as audiências de conciliação em 13 de dezembro de 2014).

Nas primeiras linhas do diário de campo e do ponto de vista dos moradores da Vila da PAZ o que eles têm experienciado no cotidiano refere-se ao conjunto de violações de direitos a moradia. O problema do esgoto a céu aberto, a poluição sonora, a grande ocorrência de acidentes ao longo da rodovia, a dificuldade de acesso a equipamentos públicos como escola e saúde constituem-se pautas presentes de reivindicação dos moradores da Paz, tema que precisa ser levado em consideração nos estudos sobre ocupações na cidade e nos próprios processos de remoção, visto que ao contrário do que tem acontecido no cenário internacional, à cidade de Belo 
Horizonte tem apresentado a diminuição no número de favelas, de seus moradores, o que indica um aumento e intenso movimento nos processos de remoção e desfavelização (LIBÂNIO, 2016).

Sendo assim, o objetivo central da pesquisa consistiu em estudar a experiências das famílias moradoras da Vila da Paz, uma das vinte e sete vilas que compõe o anel rodoviário, que está em processo de remoção e então, pensar as possibilidades de reinvenção do morar, a partir da lógica narrada pelos moradores que ali residem (ou residiram) diante do quadro de violações ao direito à moradia digna que não vivenciam, e também da situação de sofrimento social, produto dos efeitos nocivos das relações de poder que caracterizam os processos de remoções das vilas existentes na cidade. Podemos localizar ao longo dos nossos estudos uma inflexão nas intervenções governamentais, no sentido de não visibilizar a luta dos movimentos sociais que não concordam com as remoções forçadas, e no reforço da não garantia das famílias ao direito de permanência no local e também de implantação de políticas urbanas que não contemplam o direito de decidir das famílias.

O cerne do problema de pesquisa do presente trabalho consiste em compreender, por meio de uma aproximação do cotidiano de vida dos moradores da vila da Paz, as dimensões psicossociais que perpassam a cidade, as ocupações e o modo como esses moradores reinventam o morar, e sobrevivem em meio aos processos de remoção realizados de forma arbitrária, sem levar em conta, na maioria das vezes, o que os moradores esperam do lugar para o qual serão reassentados.

Ao longo dos estudos bibliográficos realizados, nota-se que a cidade é estudada e vivida por meio de alguns eixos classificatórios, que ora reforçam lógicas sob perspectivas do indivíduo, e outrora colocam em pauta questões sociológicas que circundam a cidade, associando-a ao capitalismo e a perspectivas economicista, que reforça como o poder político tem na economia sua razão de ser histórica, o princípio de sua forma concreta e do seu funcionamento atual" (FOUCAULT, p.175, 1979). Uma análise crítica desses estudos coloca para este trabalho, o desafio de pensar a cidade em seus entremeios, a cidade entre o sujeito e a sociedade, entre o urbano e o rural, entre a favela e o centro, entre a favela e os processos de desfavelamentos, entre remoção e reassentamento. É no entre que esse estudo buscou acontecer. O entre apresenta muitas contradições que possibilitam compreender a dinâmica associada aos multilineares discursos sobre a cidade. Afinal, o que você vê quando olha para a cidade? O que eu vejo quando olho para cidade? O que nós vemos quando estamos na cidade? 


\section{UMA VILA NO ANEL: PRIMEIRAS APROXIMAÇÕES}

Os vários jeitos de olhar para cidade, e os marcadores que atravessam nosso olhar para ela são reveladores para dizer da nossa relação com o jeito de ocupar, de estar na cidade e se construir como cidadão. Sendo assim, "ter apenas uma postura de cobrança sobre a cidade é empobrecer a relação e os sentidos com a cultura e a comunicação: a densidade e a complexidade urbana nos convidam ao reconhecimento da mobilidade e de seus vários centros e funções" (BARROS, 2005). Olhar para as ocupações presentes na cidade, e para as vilas que circundam o anel rodoviário, é questionar a lógica de acesso à cidade e os processos de desigualdades que ali se mantém.

O jeito que os moradores olham e vivem na Vila da Paz representa forte relação simbólica entre a vila e a cidade de Belo Horizonte, parte cheia de construções de sentido sobre o morar, o ocupar e o resistir. Conforme relato do diário de campo e a partir da imersão no mesmo observa-se que a Vila da Paz aparece no relato de vários moradores como uma ocupação do Anel Rodoviário de Belo Horizonte, caracterizada por famílias que vieram de outras favelas da cidade de Belo Horizonte e também do norte de Minas Gerais:

"Olha moça eu moro aqui tem 25 anos, ou seja, desde quando esse lugar aqui foi fundado, comecei morando em barracão de lona e vim do norte de minas para cá. Gosto de morar aqui, pois foi aqui que eu construí minha casa. A Paz é um lugar bom onde nenhum morador mexe com ninguém. Cada um no seu canto. Antes de morar aqui, morei também na favela do bairro São Paulo, aqui mesmo na região, achei esse terreno e me mudei para cá e construí essa casa. Trabalho com reciclagem; De vez enquanto aparece gente querendo saber de mim, do meu trabalho. Não tenho vontade de sair daqui não. O posto e a mercearia são próximos aqui de casa. O único problema é o tráfico de drogas, o que atrai uma forte atuação da Polícia Militar, aqui é sossegado, ninguém mexe com ninguém". ("Sic" - Fala de um senhor de 74 anos de idade, morador da Vila da Paz/ Fragmentos do Diário de Campo).

Vale destacar que a Vila da Paz fica situada geograficamente entre os bairros Palmares, Universitário, Santa Cruz e Maria Virginia, na região nordeste de Belo Horizonte, como podemos ver no mapa abaixo, formando a imagem de um delta cortada pelas ruas contornos e nacional e pelo Anel Rodoviário: 


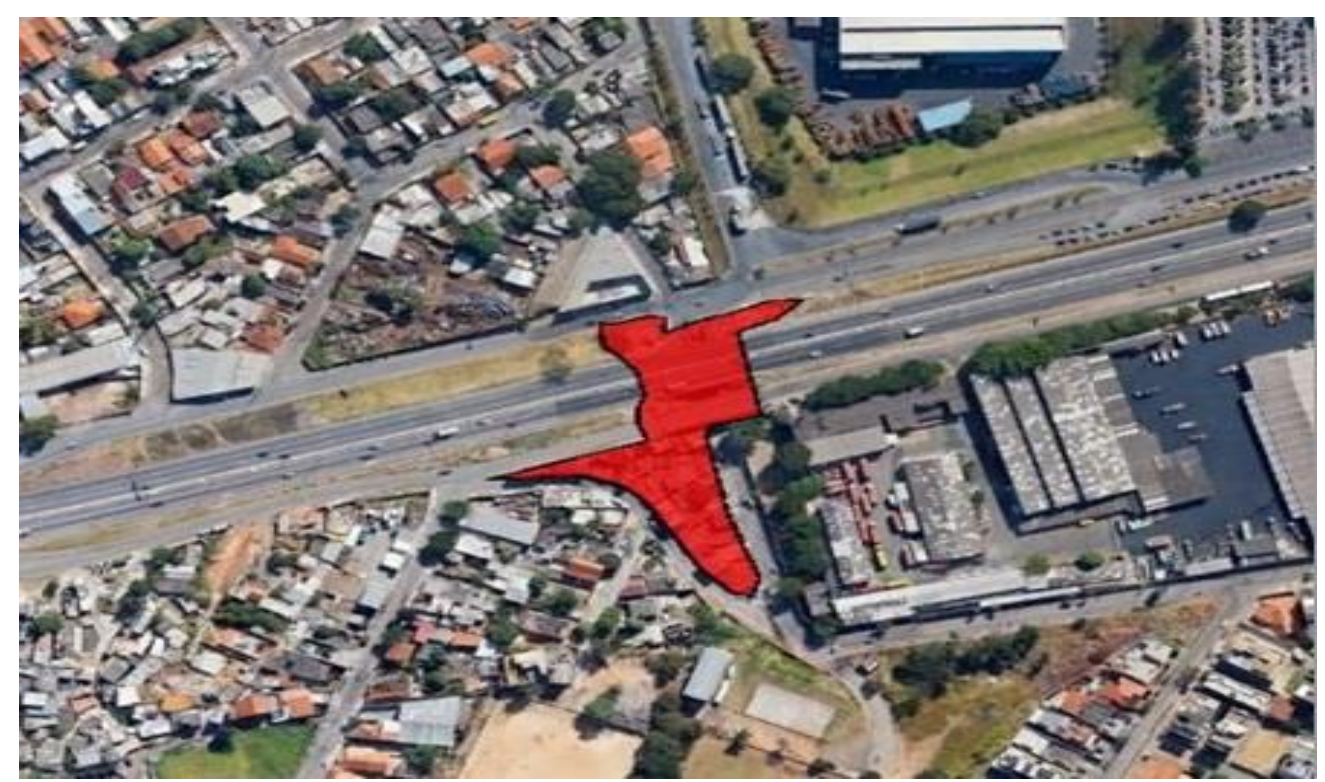

Fonte: Vila da Paz em Delta http://conciliabr381.com.br/wp-content/uploads/2016/02/Vila-da-Paz.jpg

Por estar localizada no entorno do anel há muitas opções de ônibus que passam pela Vila, que tem um alto fluxo de carro o dia inteiro, conforme narrativa dos moradores. E ao mesmo tempo esse fluxo constante de carros e o ônibus, traz um paradoxo para os moradores, já aumenta ainda mais quando é final de semana e feriado, o que contribui para a poluição sonora e visual do local.

O anel rodoviário de Belo Horizonte é considerado uma grande via de Belo Horizonte construída na década de 1950, cujo objetivo era desafogar o trânsito e o crescente número de carros e cargas que passava pelo centro de Belo Horizonte É importante destacar que o anel perpassa algumas das principais vias da cidade, como por exemplo, as avenidas Cristiano Machado, Antônio Carlos, Carlos Luz (Catalão), Pedro II, Amazonas e a Via Expressa. A Vila da Paz, de acordo com os moradores, é uma vila relativamente pequena, que tem se tornado ainda menor, pós remoções parciais já realizadas para implantação de um viaduto no local. Com a realização dessa obra, as famílias que moravam debaixo do viaduto saíram. A vila da Paz tem cerca de noventa e três domicílios, e abriga entorno de duzentos e sessenta e sete famílias, (Dados disponibilizados por meio de cadastro social realizado no local no ano de 2015 pela Justiça Federal). Os moradores da Vila trabalham em fabricas próximas ao anel e outros de forma autônoma, como ajudantes de pedreiro, realizando serviços de âmbito familiar, reciclagem, vendedores ambulantes, dentre outros. Um aspecto que nos chama atenção no cotidiano da Paz é a presença de comércio local, muitos moradores têm junto de sua residência, restaurantes, salões, bares e feiras. 
Os laços de vida comunitária na Vila da Paz é algo marcante e muito presente, o que diz da organização das pessoas na Vila para vivenciarem os aspectos de lazer, já que organizam festas no campo de futebol existente na vila, as conversas cotidianas e matinais que tem sobre a vida na rua, a mobilização dos jovens para organizarem torneios de futebol, para irem a parques próximos a Vila da Paz, como o Parque Ecológico do bairro Universitário e o Parque Renato Azeredo, dentre outros aspectos que para os moradores são elementos fortalecedores, aspectos que se constituíram como eixos analíticos do nosso estudo etnográfico.

Enquanto pesquisadora que está imersa em uma parte da cidade de Belo Horizonte, que é a Vila da Paz, percebo a Vila em sua poesia, sons, rumores, luzes, sombras, personagens, pichações, fotografas, relações e paisagens:

\section{Fotografia I: O viaduto e a Vila - Fotografia feita em 22/10/2016 na Vila da Paz.}

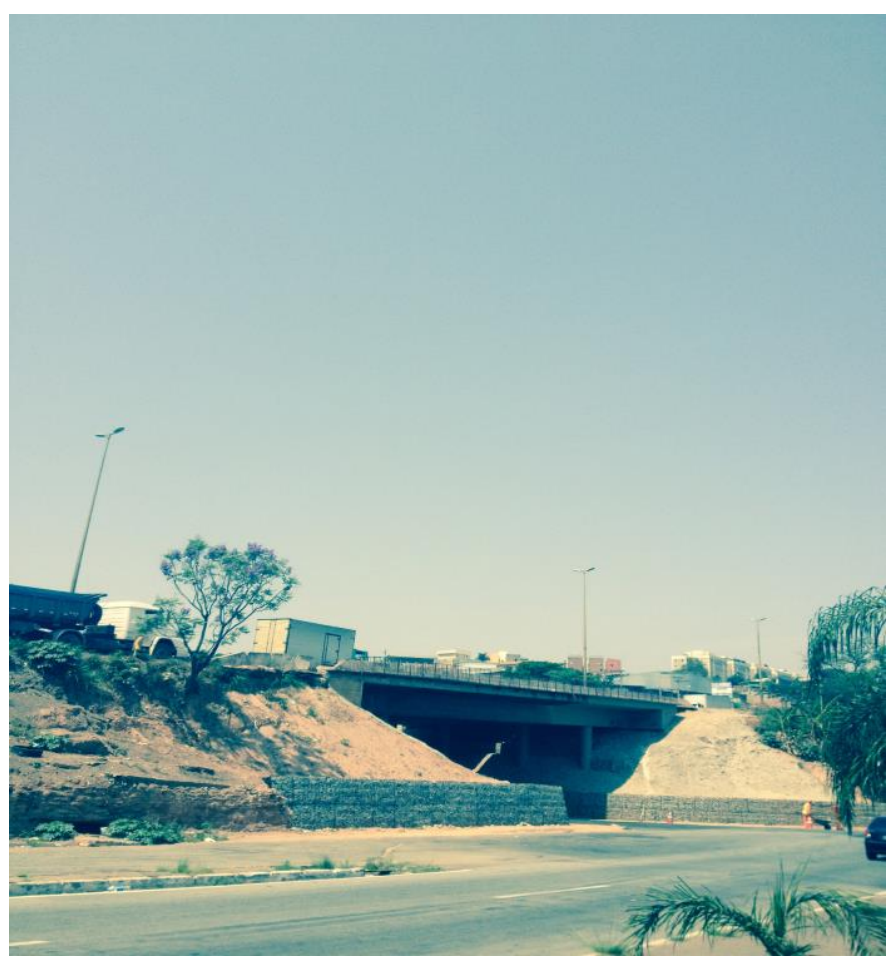

Antes de mostrarmos mais retratos de resistência da Vila da Paz, que se encontra em um grande centro urbano e não está desconectada de sua dinâmica, abordaremos a cidade, como um importante problema quando pensamos na temática da remoção. Mais adiante retomaremos a Vila pelos moradores. 


\section{INTERPRETAÇÕES SOBRE A CIDADE: A CONSTRUÇÃO DE UM OLHAR ENTRE}

Estudos clássicos sobre a cidade buscam interpretá-la a partir de eixos, que compreendem a cidade, ora associada ao capitalismo, ora individualizada no sofrimento dos sujeitos. Neste sentido, concordamos com MAGNANI $(1996$, p.23) que diz:

Não se pode ler a cidade a partir de um eixo classificatório único: é preciso variar os ângulos de forma a captar os diferentes padrões culturais que estão na base de forma de sociabilidade que existem, coexistem, contrapõem-se ou entram em confronto no espaço do cuidado.

Buscamos compreender assim, a cidade por meio de leituras analíticas mais fluidas, no sentido de estabelecer um diálogo entre perspectivas mais sociológicas sobre a cidade e perspectivas mais individuais, buscando assim compreender as relações entre ocupação de espaços e relações de poder. (FOUCAULT, 1982). Observamos ao longo da realização desta pesquisa, que a forma como vemos a cidade, e nos localizamos nela, constitui-se um ponto essencial para compreendermos as dinâmicas dos processos de remoção e reassentamento na Vila da Paz.

Uma importante influência que gerou uma nova concepção de cidade no âmbito dos estudos teóricos sobre o tema foi a Escola de Chicago com a proposição da Ecologia Urbana, a qual traz uma reflexão inédita sobre a cidade, compreendida como "laboratório social". (GRAFMEYER, Y; JOSEPH, 1979). Marcada pelo empirismo, a Escola de Chicago está interessada em pensar estudos concretos que possam contribuir para certa organização para a cidade considerada "caótica" e produzida pelo processo de industrialização, no contexto dos Estados Unidos da primeira metade do século XX.

Diante de fenômenos como: grande crescimento populacional, enorme contingente imigratório, segregação urbana, condições precárias de vida, a cidade é posta como problema. (SANTANNA, 2003). Dentro dessa perspectiva a cidade é compreendida como um espaço delimitado por critérios geográficos, números e aspectos político-administrativos. A cidade então é vista como um dispositivo que fabrica cultura urbana por meio do urbanismo como modo de vida (WIRTH, 1987). Tal perspectiva vai receber críticas como a de CASTELLS (1977), que afirmará que tomar a cidade como a própria variável explicativa não é um movimento científico, mas sim uma ideologia.

Na década de 1960, com o surgimento da escola de sociologia francesa, que questiona os preceitos de Chicago, a cidade passará ser interpretada de outra forma. Um primeiro ponto crítico da sociologia francesa 1a escola de Chicago, é o rompimento teórico com a ideia de uma sociologia 
urbana linear. A sociologia francesa tenta assim, ampliar as lentes de análise sobre a cidade, que passa a ser concebida como um espaço socialmente produzido. Neste sentido o enfoque dos estudos está na interação entre as relações de produção, consumo, troca e poder que se manifestam no ambiente urbano e ganham importância. (VALLADARES; FREIRE-MEDEIROS, 2001). E são essas relações de produção que fortalecem o movimento da cidade fragmentada.

Assim como Castells, autores como LEDRUT (1976), LEFEBVRE (1970), que também representam a sociologia francesa mantém uma inspiração marxista e questionam a ideia produzida pela Escola de Chicago, de que a cidade seria a base de explicação de todos os fenômenos urbanos. É importante lembrar que os estudos de MARX (1984) e ENGELS (1985) são clássicos para uma compreensão mais sociológica sobre as cidades já que para esses autores, a cidade se apresenta como um local de produção e reprodução do capital, fruto do processo da industrialização e está associada com a luta de classes. A cidade é caracterizada assim como produto da sociedade capitalista, portanto constitui processos sociais mais amplos (SANT ANNA, 2003).

Para a sociologia francesa a cidade produz relações de consumo, troca poder. A cidade que politiza a questão urbana gera novas perguntas, que fazem nascer novas questões sociais e também acadêmicas, como por exemplo: os movimentos sociais urbanos, os meios de consumo coletivo, a estruturação social do território na sociedade capitalista e o papel do Estado na urbanização (GONÇALVES, 1989). Sendo assim a relação entre a política urbana e as dimensões com a luta de classe, entre os movimentos sociais e o Estado são postos em pauta. (GONÇALVES, 1989). Aqui temos então, espaços para compreendermos os efeitos políticos da ocupação, elemento de análise dessa pesquisa.

Um importante deslocamento feito na obra dos autores da sociologia francesa em relação à Escola de Chicago é a compreensão da cidade como um processo social, político e econômico que não está subordinada apenas às questões do desenvolvimento capitalista.

Como contraponto, a cidade também tem sido estudada pelos sentidos que ela evoca na vida dos sujeitos, localizando aqui uma perspectiva mais focada para "olhar a cidade". No texto "A metrópole e a vida mental" de SIMMEL (1979, p.39) temos esse exemplo, visto que o autor busca compreender em seus estudos, como a cidade configura a subjetividade de seus sujeitos:

Uma investigação que penetre no significado íntimo da vida especificamente moderna e seus produtos, que penetre na alma do corpo cultural, por assim dizer, deve buscar resolver a equação que estruturas como a metrópole dispõem entre os conteúdos individual e superindividual da vida. Tal 
investigação deve responder à pergunta de como a personalidade se acomoda as forças externas.

Assim, notamos que é por meio das cidades, que os sujeitos desenvolvem seus modos de vida, se comunicam e se organizam de distintas formas identitárias. A cidade é aquela que gera sentidos, e ao mesmo tempo sofrimento aos sujeitos que nela vivem.

Sobre essa questão BORDIEU (1987) realça que a cidade, enquanto construção simbólica de grupos - inclusive daqueles grupos que pesquisam cidades, atribui a ela um papel de mercado, não apenas porque possibilita trocas materiais, mas também trocas simbólicas. A cidade é produtora de subjetividades, sonhos e temores. Sendo assim, aqueles que não estão nas pautas centrais da cidade vivem o "peso social" de serem reconhecidos como sujeito da falta e experimentam o sofrimento social, o qual deixa marcas psíquicas, com pouca visibilidade social (CARRETEIRO 2003), como o caso dos moradores da Vila da Paz, que lutam em seus movimentos de resistências, mas ainda assim, tem seus movimentos (in) visibilizados.

Outra perspectiva que também analisa a cidade com mais enfoque no sujeito- são os estudos sobre o conceito de sofrimento social que emergiram nas últimas décadas e tem sido muito utilizados no campo das ciências humanas e sociais para analisar relações consideradas como profundas entre a experiência subjetiva do mal-estar e os processos históricos sociais mais amplos. Segundo PUSSETTI e BRAZZABENI, (2001) o conceito vem sendo utilizado nos estudos sobre juventude, saúde pública, migração, cidades e outros. Os autores pontuam também sobre a ambiguidade do conceito de sofrimento social:

Por um lado, a análise das intervenções sociais para aliviar o sofrimento dos sujeitos definidos como "vulneráveis" e que frequentemente resultam na sua intensificação; por outro, a problematização das mesmas intervenções, que classificam os sujeitos em categorias rígidas, através de mecanismos complexos de patologização, criminalização e exclusão social. (PUSSETTI, BRAZZABENI, 2001, 467).

Podemos dizer então, que as perspectivas que estudam a cidade, com enfoque no sujeito tem a preocupação de pontuar as situações de sofrimento social, mal-estar e invisibilidade evocadas pelo espaço da vida na cidade, que também são muito importantes. A ideia do presente trabalho é dialogar com as leituras mais sociológicas com as perspectivas mais individualizantes para teceremos lentes analíticas sobre os processos de remoção da Vila da Paz.

A ideia de retomar algumas perspectivas clássicas em nossa pesquisa se deu com intuito de produzir análises que não "encaixem" a cidade sobre uma perspectiva ou outra, e sim que busque estabelecer um diálogo entre as mesmas. Esse se constitui um importante exercício dessa pesquisa, ver as cidades em seus diferentes retratos teóricos e os efeitos que essas leituras 
produzem na vida cotidiana dos moradores e interlocutores dessa pesquisa. Buscamos assim afirmar uma perspectiva que não reduza a experiência na cidade a uma leitura macroestrutural ou individual, mas que pretende ver isso em relação. Entrelinhas, entre teorias, entre sujeitos.

Faz-se ainda importante, destacar os estudos sobre as cidades no contexto latinoamericano, iniciados entre os anos de 1950 e 1970, e quando falamos sobre cidades latinoamericanas e brasileiras evocamos dois paradoxos: o primeiro, o qual está associado às grandes metrópoles e seus problemas permanentes como, por exemplo, pobreza, encortiçamento dos centros históricos, violência, grande urbanização, e um segundo associado às denúncias que os contextos latinos - americanos possibilitam: "De qualquer modo, nossos apelos à "cidade latinoamericana" oscilam entre a necessidade política da identidade e a denúncia, entre o ceticismo acadêmico da diferença e da ponderação". (GORELIK, 2005). No contexto brasileiro o debate sobre as cidades começa na década de 1960, a partir de uma reflexão sobre as temáticas da urbanização e desenvolvimento. Nesse período encontraremos estudos que propuseram discutir a temática do urbano em que abordavam a marginalidade e a pobreza a partir da questão das desigualdades socioeconômicas (QUIJANO, 1978; JOSÉ NUN, 1972) assim como pesquisas que se dedicaram ao estudo sobre pequenas comunidades urbanas por meio de um viés antropológico (Francisco de Oliveira, Paul Singer, Maria Célia Paoli, Manoel Tostes Berlink,) e que abordaram a marginalidade que se apresentava nas cidades brasileiras resultado não do problema de integração social, mas de problemas estruturais (SANT'ANNA, 2003).

No caso brasileiro, as cidades foram pensadas, a partir dos modelos europeus, em que o modelo de urbanização deveria instaurar o mito da modernidade. A literatura e as artes constituem uma importante expressão desse momento. As obras de Tarsila do Amaral e Mário de Andrade ilustram em arte a cidade brasileira. (JAGUARIBE, 1987):

Alturas da Avenida. Bonde 3. Asfaltos. Vastos, altos repuxos de poeira sob o arlequinal do céu ouro-rosa-verde.... As sujidades implexas do urbanismo. Filets de manuelino. Calvícies de Pensilvânia. Gritos de gnosticismo. Na frente o trem da irrigação, Onde um sol bruxo se dispersa. Num triunfo persa de esmeraldas, topázios e rubis... Lânguidos boticellis a ler Henry Bordeaux. Nas clausuras sem dragões dos torreões...Mário, paga os duzentos réis. São cinco no banco: um branco, um noite, um ouro,um cinzento de tísica e Mário...Solicitudes! Solicitudes! Mas...olhai, oh meus olhos saudosos dos ontens. Esse espetáculo encantado da Avenida! Revivei, oh gaúchos paulistas ancestralmente! E oh cavalos de cólera sanguínea! Laranja da China, laranja da China, laranja da China Abacate, cambucá e tangerina! Guarda-te! Aos aplausos do esfuziante clown, Heróico sucessor da raça heril dos bandeirantes, Passa galhardo um filho de imigrante, Louramente domando um automóvel! (MARIO DE ANDRADE, 1978). 
No trecho do poema acima intitulado "O domador", o escritor Mário de Andrade refere-se à cidade de São Paulo e suas urbanidades expressas pelo movimento da Vida Cotidiana. O modernismo, os traços que se referem à velocidade presente na vida urbana e também os processos comunicativos são bem evidenciados no trecho acima.

Na obra abaixo, cuja autoria é de Tarsila do Amaral, a artista faz menção a uma cena comum na cidade brasileira que é a chegada das famílias imigrantes ao Brasil para o trabalho na lavoura na era Vargas. O semblante de cansaço e desesperança dos imigrantes que nos convida a pensar o momento de crise econômica e social que o Brasil passava em busca dos imperativos do desenvolvimento e urbanização, fenômeno que traz a cidade como objeto de estudo importante para o cenário brasileiro.

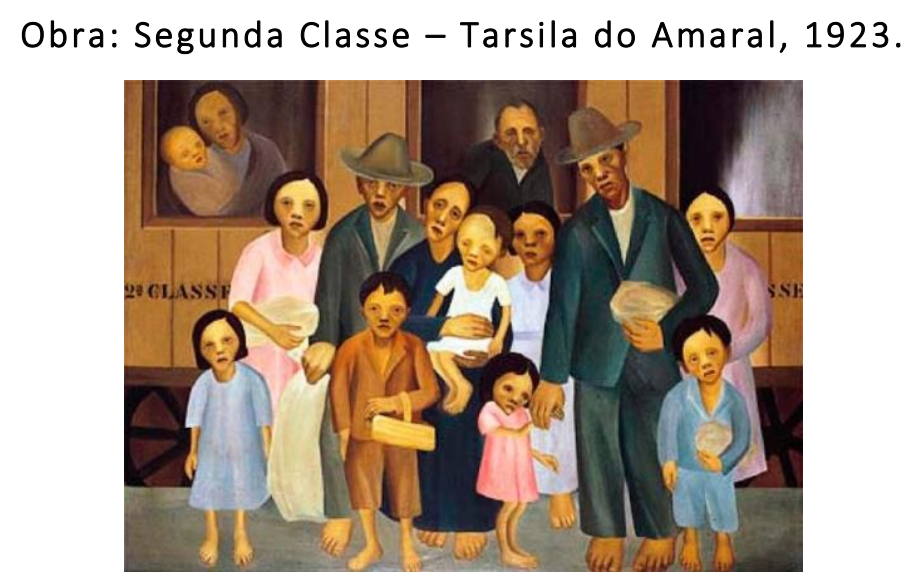

Segundo FERNANDES e GOMES (2004) os estudos sobre cidades no Brasil se intensificam na década de 1980, a partir do problema da crise de moradia que se agravava. A questão habitacional então surge como uma demanda de pesquisa e intervenção. Esses autores em estudos realizados constataram que $2 / 3$ dos trabalhos analisados sobre a temática de cidades no Brasil, dizem respeito às transformações que ocorreram nas cidades do interior, sendo a maioria das pesquisas associadas a cidades que ficam no sudeste do Brasil. Notamos que a habitação como um problema é uma tônica bem recorrentes nas cidades brasileiras também nos dias de hoje.

De acordo com ABREU (1994) muitos trabalhos surgiram no Brasil na década de 1994 sobre a cidade brasileira enfocava termos dos seus padrões urbanos e processos sociais sobre suas origens. Entretanto, eram trabalhos muito vinculados aos estudos da geografia e tinham como objetivo olhar para a cidade em suas perspectivas físicas. Já as questões sociais e políticas apareceram em um segundo momento. Observamos ao longo da realização da etnografia da Vila 
da Paz - que essa preocupação com os aspectos geográficos da remoção é muito forte, e pouco se fala sobre a participação das famílias removidas no planejamento dos processos de remoção e reassentamento bem como sobre as desigualdades sociais que marcam suas experiências.

Assim, a partir dos anos 1980 há uma preocupação em buscar por meio da pesquisa histórica, compreender os antecedentes históricos e políticos associados à crise da moradia. A partir desse momento há menos uma preocupação com a "forma" da cidade e sua geografia, e mais uma preocupação com elementos sociais, todavia não com a força suficiente para que os aspectos sociais sejam visibilizados o tanto quanto se fazem necessários.

De acordo com FERNANDES ET AL (2004), a partir de pesquisas realizadas sobre quem pesquisava a cidade brasileira na década de 1990, temos elementos interessantes, como por exemplo, os temas das modernização urbana, urbanismo, habitação e imagem/imaginário fazem da agenda de estudo dos pesquisadores. O que notamos é que o campo de pesquisa sobre cidades nesta década se desloca da geografia e concentra-se na arquitetura. Encontraremos uma contraposição e estudos críticos sobre o autoritarismo das políticas elitistas, a segregação/exclusão enquanto elementos condutores das políticas urbanas temos também a recusa aos prevalentes estudos que entendiam a cidade em uma perspectiva funcionalista, e o combate ao "ahistoricismo" modernista dos anos de 1950/60.

Outro aspecto importante para pensarmos sobre a história da cidade no Brasil é o fato de termos a República inaugurada com os ideais de liberdade, ordem, ciência e progresso, por meio de um golpe militar. Com a emergência da nova república, a construção de uma nova cidade é arquitetada em prol de o emergente poder republicano, junto com a ela várias medidas foram tomadas para impedir o acesso à terra, restringindo também o acesso à escolaridade dos operários que trabalhariam na construção da nova cidade. Neste sentido, concordamos com Foucault (1982), quando afirma que a cidade reflete questões não somente associadas à produção capitalista, como também aos problemas da arquitetura, da população, da saúde, das questões urbanas. " (...) depois, no final do século XVIII, novos problemas emergem: torna-se uma questão, usar a disposição do espaço para fins económico-políticos. " (FOUCAULT, 1982). Para esse autor os estudos sobre as cidades envolvem a reflexão sobre a arquitetura das mesmas, na maioria das vezes, pensada em função dos objetivos e técnicas dos governos e das próprias sociedades:

Interroga sobre como deve ser a ordem de uma sociedade, o que deve ser uma cidade, tendo em conta as exigências de manutenção da ordem; e tendo em conta, também, que se devem evitar epidemias, evitar revoltas, permitir uma vida familiar decente e moral. Em função desses objetivos, como conceber simultaneamente a organização de uma cidade e a

Revista de Direito da Cidade, vol. 09, no 1. ISSN 2317-7721 pp. 233-275 248 
construção de uma infraestrutura coletiva? Como devem ser construídas as casas? Não estou a dizer que este tipo de reflexão não aparece senão no século dezoito, digo apenas que no século dezoito tem lugar uma reflexão profunda e geral sobre estas questões. Se consultarmos um relatório policial da época - os tratados estão consagrados às técnicas de governo descobre-se que a arquitetura e o urbanismo ocupam um lugar extremamente importante. (FOUCAULT 1982)

Outra importante contribuição de Foucault para cidades é o fato de ele evidenciar em sua obra a presença de um marco político importante nos escritos sobre a arte de governar a partir do século dezoito. Esses escritos passam a incluir dimensão do significado político emersos no urbanismo, nos equipamentos coletivos, nas políticas higienistas e na arquitetura privada. As cidades então, entre os séculos dezessete e dezoito, começam a se tornar uma preocupação para aqueles que governam, e para os sujeitos que ocupam os espaços públicos. Sendo assim,

"A cidade deixa de ser compreendida como um lugar privilegiado, uma exceção num território de campos, florestas e estradas. As cidades deixam de ser ilhas que escapavam à lei comum. Pelo contrário, com os problemas que levantavam e as formas particulares que desenvolveram, as cidades passam a servir de modelo para uma racionalidade governamental que se aplicará ao território no seu conjunto". (FOUCAULT, 1982)

Um aspecto importante nos estudos Foucautianos é que o Estado é comparado a uma grande cidade, a capital seria sua praça central e as estradas suas ruas. E um Estado bem organizado, como relata o autor, é aquele que tem um sistema de policiamento e vigilância bem apertado. A polícia incialmente era vista como um conjunto de regulações para manter uma espécie de tranquilidade na cidade, todavia na cidade que emerge nos estudos de Foucault, a polícia é uma espécie de racionalidade que se estende como referência a todo território. Para além da relação espaço-poder FOUCAULT (1982) nos convida a pensar também sobre as revoluções urbanas que ocorrem como efeito do controle do espaço. São resistências que provocam as transformações da população, as mudanças de comportamento das pessoas.

O que nos chama atenção nos estudos sobre a cidade de contornos latino-americanos, e especialmente do Brasil é que o crescimento das favelas está intrinsicamente ligado ao processo de urbanização na década de 1960-1970. E observamos que a literatura coloca o agravamento da questão habitacional no país. Como afirma MARICATO (2005) "cidades estão piorando muito" e isso envolve uma série de efeitos no âmbito da mobilidade urbana, poluição ambiental, segregação urbana, dentre outros. É nesses aspectos que nos debruçaremos agora, com enfoque especifico, no caso da ocupação da Vila da Paz, em Belo Horizonte. 


\section{O SURGIMENTO DA CIDADE DE BELO HORIZONTE: NO MEIO DO CAMINHO TEM UM} ANEL

Belo Horizonte nasceu de um projeto científico sobre o que seria uma cidade capital, conhecido como o Arraial de Belo Horizonte (antigo Curral Dey Rel, 1890 (BARROS, 2005)). E já no início do projeto urbanístico da cidade, a remoção de uma parte da população já foi encomendada - já que o empreendimento Belo Horizonte deveria reunir condições higiênicas que a identificasse como grande cidade, como descreve um cronista da época:

O tipo geral deste povo é doentio. Magros, amarelos, pouco desempenados na maioria. Havendo uma grande proporção de defeituosos, aleijados e raquíticos. Ora, esta fisionomia quase geral da população de Belo Horizonte desarmoniza completamente a amenidade do clima, com o ar seco e batido quase constantemente pela brisa, com a natureza do solo que é magnifica (CAMARTE, apud ASSIS, 1995, p.9).

Notamos que há uma preocupação com as questões geográficas, no que possibilitam a construção da cidade, e uma perspectiva de higienização social. E sobre essa perspectiva, Foucault nos traz grandes contribuições para pensarmos sobre a geopolítica da cidade. Para o autor as preocupações higienistas são muito presentes na arquitetura da cidade que tem o seu desenho urbanístico pensado para a regulação da ocupação do espaço, do controle sanitário da cidade. E esse controle sanitário não diz apenas da organização do espaço, mas da higiene dos pensamentos e sentimentos (o que o autor chama de higiene mental) são estratégias de controle presente na construção das cidades. (FOUCAULT, 1999; 2008), o que integra o movimento remocionista presente na década de 1980 na cidade de Belo Horizonte.

Até 1980, predominaram na cidade as políticas remocionistas, que buscavam a desfavelização (LIBÂNIO, 2016). Entre o período de 1971 a 1982 foram removidas quase 10 mil famílias assentadas, o que totalizou 68 mil famílias afetadas (LOPES, 2010). É importante lembrar, que também em 1980, com a emergência de movimentos sociais em defesa da habitação em Belo Horizonte a visão sobre o que é ser morador de favela modificou muito, já que os moradores invadiram a Prefeitura da cidade em 1981 para reivindicar reconhecimento das favelas. Sendo assim, o poder público começou a reconhecer as favelas como parte integrante da cidade do ponto de vista urbanístico e jurídico. Todavia, na década de 1990 a Companhia Urbanizadora de Belo Horizonte (URBEL) começou a concentrar suas intervenções apenas na urbanização das favelas, o que gerou uma grande diminuição na legalização de terras que já estavam ocupadas por moradores. Podemos dizer assim, que nesta época a Política Urbana de Belo Horizonte estava preocupada mais em urbanizar do que promover regularização fundiária. 
Paralelamente a esse movimento, nos períodos que marcam a década 1990 até 2000 notamos que os processos no âmbito de participação popular ganham outra tônica com o Estatuto das Cidades que prevê novas metodologias de planejamento urbano, que procurou conciliar o direito à cidade, a urbanização e os processos de regularização fundiária, Antes de fazer qualquer intervenção a URBEL precisava elaborar o Plano Global Específico (PGE) dos territórios, todavia vários descompassos aconteceram entre o objetivo da intervenção urbana e a garantia ao Direito à cidade, e as práticas de desvafelamentos, nos últimos 10 a 15 anos, são frentes recorrentes da Política Urbana em Belo Horizonte. Várias remoções têm sido feitas de maneira arbitrária com o objetivo de melhorar a mobilidade na cidade, como a própria obra de duplicação do anel rodoviário - obra que inclui a remoção de 27 vilas ao longo do anel rodoviário; A linha Verde, que liga o centro de Belo Horizonte ao aeroporto de Confins, que foi responsável por remover do mapa da cidade as vilas São Paulo/Modelo, Carioca, Real, Maria Virgínia e São Miguel/Vietnã, além de outras vilas que ficam na região Pampulha e Noroeste. Dentre outras intervenções urbanas que incluem remoções forçadas. No caso da Vila da Paz há muitos moradores que eram da Ocupação Vietnã, e foram expulsos para a construção da linha verde, e com a indenização irrisória que receberam ocuparam a Vila da Paz. Nos anos de 1995 e 2005 foram realizadas 2.866 remoções com a justificativa de realização de obras públicas na cidade (LOPES, 2010).

Um ponto muito problemático dessas remoções em virtude da suposta melhora das vias da cidade é o fato da retirada das pessoas das ocupações de forma arbitrária e também o reassentamento das mesmas em unidades habitacionais verticais que não contemplam os aspectos culturais que os moradores tinham, como por exemplo, a criação de bichos em casa, outros trabalham com materiais recicláveis, dentre outros aspectos e sonhos que não cabem dentro de um apartamento, ou de um novo circuito de circulação na cidade - que não contempla as relações sociais até então estabelecidas. As indenizações recebidas pelos moradores também são insuficientes para que possam adquirir outro imóvel e acabam migrando para lugares muitos distantes da cidade, como relatam alguns moradores da Vila da Paz.

Esse cenário atual, de forte presença de políticas de habitação remocionistas na cidade de Belo Horizonte - nos remete aos escritos de Foucault sobre a questão da medicalização dos espaços. FOUCAULT (1979) teve como objetivo em seus estudos sobre a cidade - observar de forma minuciosa como a medicina social é um dispositivo orientador para a urbanização das cidades (como podemos ver no trecho do cronista Camarate sobre a população de Belo Horizonte). 
Algumas obras que realçam essa temática de estudo do autor são Vigiar e Punir (1999) e o curso sobre Segurança, território e população (2008). Nessas obras Foucault aponta três modelos de análise que apontam para a correlação entre repartição dos corpos e ocupação do espaço: o modelo da lepra - o qual cria e divide em categorias sociais leprosos separados dos não leprosos produzindo efeitos de exclusão social do primeiro grupo. O segundo modelo que faz referência a gestão da peste, o que possibilita quadricular a cidade e gerenciar estratégias de vigilância e o último que atuava na cidade a partir dos cálculos probabilísticos de epidemias e endemias como a varíola.

Podemos dizer então que na concepção dos estudos Foucaultianos, a cidade e a ocupação de seus espaços têm uma repartição funcional, justificada pelo governo e pelo saber jurídico, no sentido de controle e medicalização dos modos de vida, o que o autor chama de projeto biopolítico e no caso de Belo Horizonte há uma forte presença de práticas de remoção que fortalecem o discurso higienista de expulsão das ocupações da cidade.

Nesse projeto os espaços a serem ocupados (creches, escolas, locais de lazer, unidades de atenção à saúde, dentre outros) são organizados especificamente para determinados grupos para ordenar as multiplicidades por meio de uma perspectiva de expansão da vida. A presente pesquisa teve como um dos seus objetivos analisar o projeto biopolítico de remoção das famílias da vila da Paz para a implantação de um grande empreendimento, que é a duplicação do anel rodoviário.

É interessante notar que FOUCAULT (1979) entende as políticas higienistas e de "limpeza da cidade" como especialidades na gestão do espaço, no sentido de gerir os deslocamentos da população e controlar qualquer movimento de resistência frente à tentativa de questionamento em nome da "higiene" e ordem social. Esse movimento fica muito evidente quando analisamos o caso da remoção das famílias da Vila da Paz para outros lugares.

Conforme a estética do projeto urbanístico da duplicação do anel rodoviário, não pode haver famílias que moram ao longo do anel. É uma questão que está menos relacionada com a garantia dos direitos de morar dessas famílias, e mais relacionada com o interesse do governo em higienizar os rastros de pobreza que atravessam Belo Horizonte. Ações que podemos ver nos processos da chamada "urbanização" das Vilas e Favelas, nos casos de remoção de famílias no Rio de Janeiro para chegada da Copa do Mundo, da política de expulsão dos moradores de Rua de Belo Horizonte também em função da Copa.

Notamos nesses movimentos de remoção de famílias para a instalação de grandes empreendimentos, um controle e uma vigilância dos corpos, todavia no caso da Vila da Paz, os 
moradores têm reinventado suas formas de ocupar os espaços. As pessoas são removidas, mas ocupam novamente. As casas são seladas como um imperativo de que não podem mais passar por reformas, pois vão sair - mas os moradores reformam e reorganizam os espaços, pois o discurso de saída é uma forma de controle dos corpos há anos. Moradores relatam e pude registrar diário de campo de pesquisa, que escutam essa máxima do governo há 16 anos.

Segundo ASSIS (1995, p.8) as características da população de Belo Horizonte eram vistas como efeitos de uma cultura considerada pobre, uma forma de olhar para os moradores do antigo Arraial de forma desqualificada e devido a esse julgamento no ano de 1894, a comissão construtora de Belo Horizonte determina a desapropriação de 430 casas, com a justificativa de facilitar o desenvolvimento da obra de construção da cidade, desconsiderando tudo que ali existia. Podemos notar que Belo Horizonte já nasce com a desapropriação como pauta política e social. E é um fenômeno que se repete.

A cidade de Belo Horizonte nasceu a partir das definições de seus limites e de suas possibilidades de troca e mistura, nasce já com um paradoxo: a cidade do poder (idealizada pelo projeto modernista e científico) e os funcionários que iriam compor esse cenário e a cidade dos trabalhadores (JULIAO, 1996, P. 56). Neste sentido, o projeto de construção da cidade de Belo Horizonte traz consigo a perspectiva da segregação espacial que distinguia os ricos (funcionários do Estado, comerciantes, dentre outros) e os pobres (trabalhadores da construção da cidade). E essa segregação estava associada à diferenciação dos espaços planejados e não planejados, e com tipos diferentes de casas. O morar então estava vinculado ao status do ocupante.

O plano de construção da cidade de Belo Horizonte possui três importantes elementos para pensarmos sobre: A ênfase no sistema viário para controle da circulação, coexistências de distintas funcionalidades distribuídas de acordo com o grau de insalubridade entre área urbana e suburbana e o tratamento do estilo diferenciado de ocupação dos bairros como forma de controle dos diferentes cidadãos (MAGALHÃES E ANDRADE, 1989). Sendo assim, Belo Horizonte teve suas ruas e espaços nomeados: as avenidas grandes receberam os nomes de grandes rios (Amazonas, Tocantins, Paraná), outras homenageiam os índios (Tupinambás, Tamoios, Guaicurus) e em meio às essas nomeações nos perguntamos onde está o Anel Rodoviário neste projeto de cidade?

O Anel Rodoviário foi construído nos anos de 1970 com o seguinte objetivo: evitar o transito de veículos em direção a regiões vizinhas ou em outros Estados. (BARROS, 2005). Com a criação do anel cria-se uma fronteira: aqueles que moram em Belo Horizonte e aqueles que utilizam o anel para acessar bairros da região metropolitana. Se fizermos uma pesquisa sobre a 
história do anel rodoviário na internet, o que localizaremos são enunciados como: "Trânsito no anel rodoviário agora", "Morte no anel rodoviário", "Atropelamento no anel rodoviário".

As notícias que são divulgadas sobre o anel têm relação com suas características geográficas e físicas. Em âmbito das dinâmicas sociais e políticas que circundam o anel, o que encontramos são enunciados referentes às ocupações ao longo do anel (conforme matéria divulgada pela mídia televisiva em 15 de novembro do corrente ano). Todavia, as notícias divulgadas adjetivam as ocupações como "invasões" ilegais e colocam os moradores como aqueles que além de invadir o anel, também utilizam água e luz de forma ilegal. O que presenciamos são situações de hostilização e preconceito social das pessoas que moram ao entorno do anel e são interlocutores da presente pesquisa.

Nosso objetivo com o presente estudo é também visibilizar as lutas e formas de enfrentamento dos moradores frente aos processos de remoção que tem vivenciado em uma parte específica do anel, que é a Vila da Paz e contribuir com a visibilidade de outras interpretações sobre a cidade. É necessário reconhecer os movimentos de resistência, que têm construído outras ações práticas e políticas pelo direito à moradia e a cidade (MARICATO, 2013). Sendo assim, podemos compreender as ocupações urbanas como movimentos de resistência ás políticas habitacionais. Entendemos assim, a Vila da Paz como uma ocupação do anel rodoviário que reinventa novas formas de acesso à cidade:

As ocupações são uma realidade cabal e só não enxerga quem não quer ver. São tão intensas quanto necessárias, pois são a política habitacional mais efetiva no Brasil de hoje e ainda serão até que a reforma urbana seja feita e as cidades deixem de ser planejadas para a minoria rica, passem a privilegiar os outros $99 \%$ que a constroem todos os dias. As ocupações são espaços de saberes, de experiências populares, partes componentes do embrião que gerará o novo. (LEONARDO PÉRICLES ${ }^{4}, 2015$ )

\section{(RE) EXISTÊNCIAS COMO POSSIBILIDADES DE SER MORADOR DA VILA DA PAZ: OUTRAS INTERPRETAÇÕES}

E é nas resistências que Foucault (1982) discorre que é possivel haver uma revolução urbana, que o problema dessa pesquisa se interessou. Como os moradores da Vila da Paz, que passaram pelo processo de remoção, se organizaram? Qual a importância política do espaço-Vila da Paz para eles?

\footnotetext{
${ }^{4}$ Leonardo Péricles é coordenador do Movimento de Luta nos Bairros, Vilas e Favelas (MLB/MG) e morador da Ocupação Eliana Silva; em post no Facebook, 7 de agosto de 2015.
} 
Ao longo dos nossos estudos bibliográficos notamos que diversas áreas do conhecimento (semiótica, antropologia, história, sociologia) caracterizam a cidade como um fenômeno polissêmico, como define ALVAREZ (1995, p.10):

como um esqueleto territorial que enmarca la circulacion y el entrecuzamiento de capitales materiales y simbólicos a partir de dinâmicas que a veces execden su própria materialidade.

Dentro dessa polissemia, nos interessou identificar e compreender as vozes, desobediências e experiências dos moradores da Vila da Paz frente os desafios do morar digno. Para alcançarmos nossos objetivos, esta pesquisa, em seus aspectos metodológicos foi realizada a partir do arsenal teórico da etnometodologia, que tem como base o interacionismo simbólico e a história oral (MINAYO, 1992). Sendo assim, dentro das lentes de análise que a etnometodologia nos permite, a pesquisa lançou mão da etnografia e fotoetnografia.

A perspectiva etnográfica utilizada tem fundamento em GEERTZ (1978), antropólogo que causou grandes impactos na pós-modernidade para saberes como psicologia, história, dentre outros. A antropologia que este autor defende, é de cunho hermenêutico. O conceito de cultura em Geertz tem embasamentos na semiótica, e o autor a compreende como um conjunto unificado de sistemas, que ele chama de teias de significados, ou seja, no campo de pesquisa, elementos como o mito, a arte, a escrita, a poesia, a religião, a comunicação, a moda, a própria pessoa é um conjunto complexo de significados, e a etnografia é esta compreensão de significados por meio da inter-relação dos mesmos.

Sendo assim, o trabalho etnográfico, se dá em dois momentos, um primeiro em que o etnógrafo estabelece suas descrições superficiais - sobre aquilo que presencia no seu contexto de pesquisa, e um segundo momento é composto pela descrição densa, que é o encontro daquilo que foi observado com as teias de significado por ele interpretada, a partir da história dos atores e do conhecimento acadêmico que ele dialoga.

Já a fotoetnografia consiste na união da fotografia com a etnografia para o descortinamento da realidade que se apresenta. Não podemos falar de fotografia sem citar o trabalho de Roland Barthes (1980) que lançou na década de 1980 seu livro "A câmara clara", e nesta publicação o autor disserta que uma foto pode ter três funções "fazer, suportar, olhar" sendo assim, podemos dizer que a fotografia reúne dois aspectos: a realidade e o passado “... o que vejo não é uma lembrança, uma imaginação, uma reconstituição..., mas o real no estado passado: a um só tempo o passado e o real" (BARTHES, 1984, p.124). Com essas afirmativas 
Barthes nos convida a pensar sobre as polissemias contidas nas fotografias, na conexão entre texto imagem.

A fotoetnografia pode ser caracterizada como "uso da fotografia como uma narrativa imagética capaz de preservar o dado e convergir para o leitor uma informação cultural a respeito do grupo estudado" (ACHUTTI, 1997).

Foi a partir da união entre etnografia e fotoetnografia que essa pesquisa foi realizada, e a (re) existências dos moradores foram mapeadas e construída sobre quatro eixos analíticos, um primeiro sobre aquilo que etnografamos como desobediência dos moradores, um segundo que se constitui sobre o olhar dos moradores, o terceiro que é tecido a partir do diálogo com movimentos sociais, e o quarto que se embasa nos trâmites jurídicos do programa de remoção das famílias.

\section{A DESOBEDIÊNCIA COMO EXPRESSÃO DE LUTA PELO DIREITO À MORADIA}

Um aspecto importante desta etnografia refere-se às formas de desobediência dos moradores da Vila da Paz aos imperativos de remoção. E localizamos assim, dentro dessas desobediências- alguns aspectos que nos dizem desse movimento de questionar e existir dos moradores.

No primeiro âmbito - etnografamos a desobediência social: as remoções trazem como efeito a desagregação das relações com os mais próximos, como os vizinhos e os parentes. Elemento que fica muito forte na narrativa dos moradores. Os moradores da Paz desobedecem a esse efeito, quando mesmo em situações de remoção, eles retornam a Vila para manter os laços construídos, quando questionam o porquê de não ficarem próximos dos seus, quando se juntam com o CMAR para participarem das audiências coletivas.

No segundo âmbito - etnografamos a desobediência urbana: termo que usaremos para nos referir aos serviços precários que os moradores da Vila da Paz tem acesso, como por exemplo, não tem serviços de saneamento básico, muitos moradores fazem "gatos" para terem acesso à luz, os equipamentos públicos são distantes da Vila - contudo os moradores tem reivindicado pela Associação Comunitária existente no bairro esses serviços, tem desenvolvidos seus comércios próprios, como produção de alimentos, criação de feiras para venda de produtos orgânicos, realização de caminhadas na passarela, ou seja, o próprio fato de ocupar- já é questionar a lógica da cidade fragmentada e excludente.

No terceiro âmbito - etnografamos a desobediência econômica: os processos de remoção e reassentamento fragilizam as oportunidades de empregabilidade das famílias, quando removidos 
- muitos moradores deixam de trabalhar perto de casa, conforme relato deles, o que envolve gastos com deslocamento. Para isso, os moradores têm resistido em negociar com os agenciadores das políticas, formas de pensar o novo lugar de morar. Relatam que na maioria das vezes suas vozes não são ouvidas, mas tentam fazer ecoar de alguma forma. Os moradores também têm buscado meios alternativos de sobrevivência, a própria feira que criaram já é uma alternativa de (re) inventar e questionar o que é para eles oferecido.

Na perspectiva da fotoetnografia podemos visualizar abaixo, formas de desobediência dos moradores aos imperativos dos processos de remoção e reassentamento:

\section{Fotoetnografia de Campo: Desobediência Urbana}

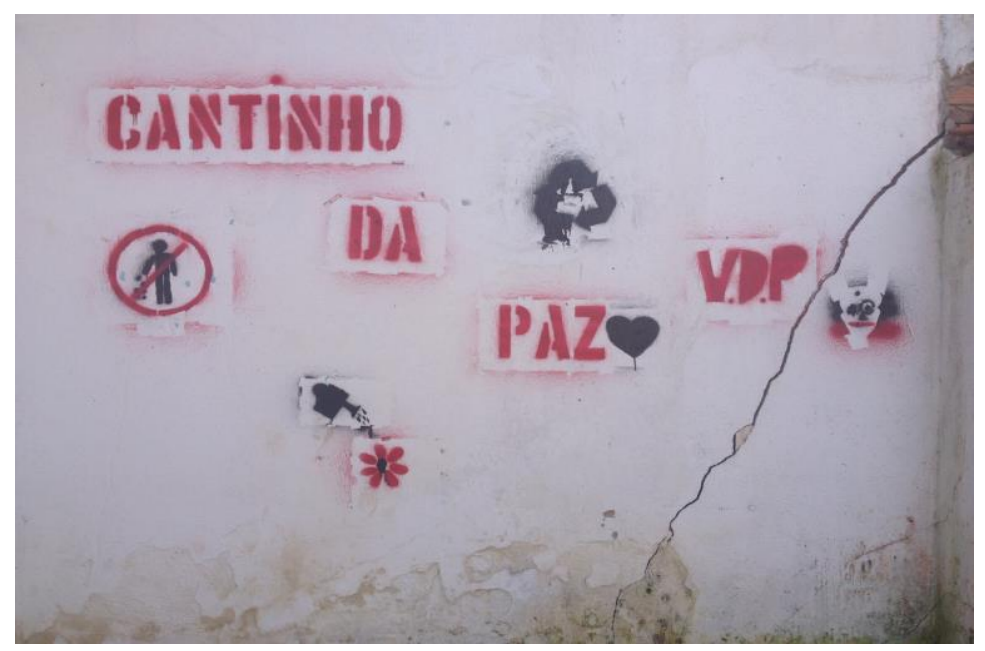

Fotoetnografia de Campo: Desobediência Econômica

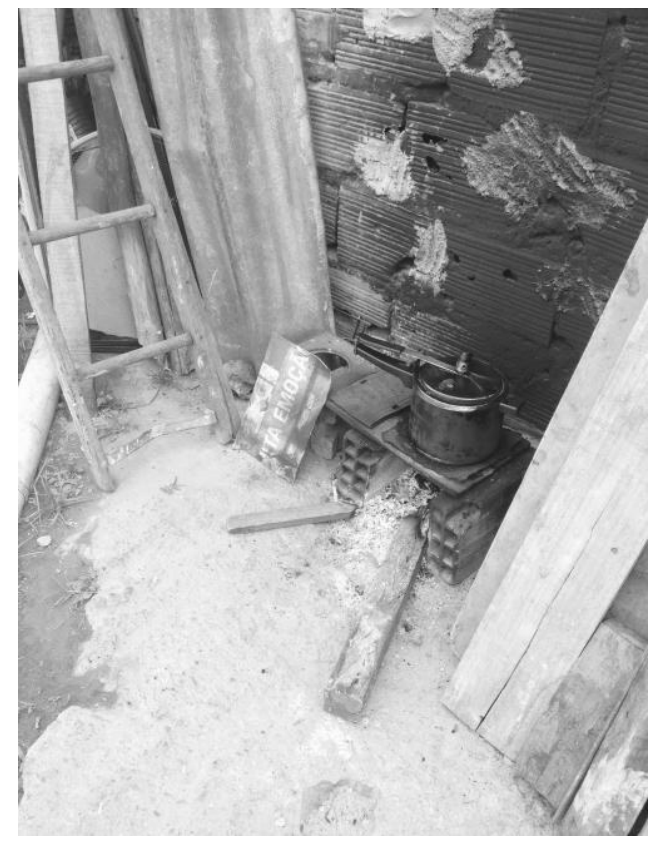


Fotoetnografia de Campo: Prosas cotidiana na Paz - Desobediência Social

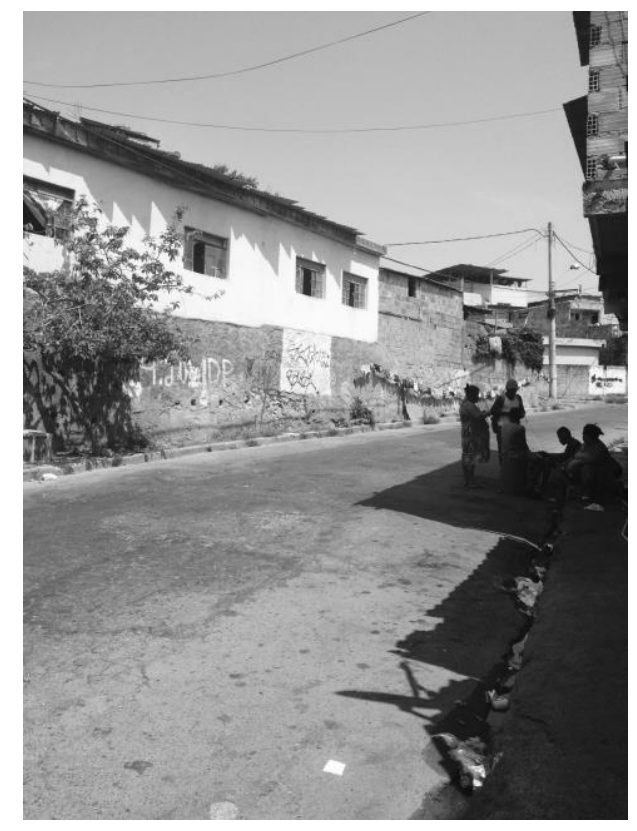

Nosso objetivo com essa etnografia não é estabelecer classificações lineares, pois sabemos que as desobediências estão todas conectadas entre si - com um objetivo maior que é questionar e operar sobre a segregação social do espaço urbano. Como afirma DAVIS (2006) em todo mundo tem ocorrido à remoção em grande escala, em âmbito global, o que traz como "consequência, os pobres urbanos como nômades, 'moradores transitórios num estado perpétuo de realocação'" (ibid., p. 106) e nos convoca ainda mais a prestar atenção nas desobediências para uma cidade mais possível e que garanta o Direito à Moradia de forma mais justa.

É nessas possibilidades de resistência, liberdade e desobediência que essa pesquisa se interessa. Como os moradores da vila da paz tem vivenciado esses processos de remoção e reassentamento? Interessa-nos analisar o significado do morar, enquanto possibilidade de (re) existir e direito de escolher, como mostram as desobediências etnografadas acima, e no próximo tópico abaixo.

\section{O OLHAR DOS MORADORES: CIRCUITOS DE RESISTÊNCIA}

Nosso objetivo neste tópico do texto é localizar os lugares pelos quais os moradores circulam e acentuar a relação de pertencimento construída com os espaços da Vila e apresentar assim, circuitos de resistência que foram construídos ao longo das inter-relações construídas. 
Compreendemos resistência como linhas de existência anônima e originária que se tornam visíveis no confronto com o poder, logo "resistir é manter essa linha simultaneamente móvel (clandestina, nômade) e imóvel (presa ao seu lugar) " (PROUST, 2002). Essas linhas possibilitam a reinvenção dos espaços na cidade e do modo de viver nela de forma coletiva.

Sendo assim moradores da Vila da Paz a expressam nos espaços de socialização e fortalecimento de vínculos comunitários, por meio das reuniões comunitárias que realizam, através da participação nas reuniões da Comunidade dos Moradores do Anel Rodoviário (CMAR) que funciona como um grupo de articulação e defesa de direitos dos moradores frente às remoções realizadas não apenas na Vila da Paz, mas também em todas as vilas ao longo do anel, formando linhas de resistência continuas que confrontam o jeito de habitar a cidade e a Política Urbana de Belo Horizonte.

Conforme narrado por eles, a Vila se constitui como um espaço de conquista, de amizade, de apoio. Relatam que já escutam o discurso da remoção há dezesseis anos, mas nada acontece. Alguns moradores relatam que já viram pessoas morrer de acidentes, e de processos naturais e ficarem sem saber se iriam sair ou não. Os moradores gostam muito de viver na Vila, pela existência de relações de solidariedade entre os vizinhos, pelo campo de futebol, pela luta que aquele espaço representa, já que muitos vieram por outros processos de remoção. Muitas famílias ao contar suas histórias falam que vieram direto da favela do Vietnã, de onde também foram expulsos, e com o dinheiro recebido pela remoção, ocuparam e construíram barracos na Vila da Paz:

\begin{abstract}
"Sou moradora da Vila da Paz e tenho 56 anos e chegamos aqui e moramos em uma casa de aluguel na Vila. Viemos de um lugar chamado Rubim. Eu cheguei aqui casada (não com o meu companheiro atual, mas com meu exmarido), só que ele morreu de acidente de carro e eu vi. Foi aqui mesmo. E depois que passou um tempo conheci meu companheiro atual, começamos a namorar e viemos morar nesta casa. Eu gosto daqui porque tem mercearia perto sabe? Fico sabendo de gente que muda e não tem nada perto de casa; Também tem Posto de Saúde, Açougue... só vou ao centro da Cidade para receber minha aposentadoria, pois aqui não tem banco. Eu morei muito tempo no interior, por isso gosto daqui. Já cozinhei muito em fogão de lenha, vim para cá, porque queria coisas e tenho minha casa. Eu vou ter que sair daqui, escuto essa história há anos, mas não quero sair, aqui é um lugar bom, sossegado, longe da cidade. O problema aqui é o tráfico de drogas, a atuação da Polícia. Moça vou ser bisavó, estou feliz demais" (Fala de moradora da Vila da Paz- Fragmentos do Diário de Campo).

O sentimento de pertencimento na Vila não é expresso somente pelos equipamentos e/ou
\end{abstract} objetos que ali estão, mas principalmente pelos sistemas de relações que foram construídas com o lugar, que é marcado pela experiência, percepção e valores. E os lugares guardam em si valores, 
que são apreendidos através das experiências com o espaço onde habitamos e com as relações intimas que ali estabelecemos. (TUAN, 1983).

O morar então está perpassado pela intersubjetividade construída entre os moradores, na relação do entre eu e o outro, que produz o Nós, como vemos na fala da moradora acima. A Vila da Paz é mencionada pelos moradores como "um lugar deles", um lugar entre eles - o que evidencia a luta por pertencimento e vinculação, diante da situação de despossessão vivenciada constantemente por eles - quando são removidos do seu lugar de forma forçada.

Em relação aos lugares que fazem parte do cotidiano da Vila da Paz temos os serviços públicos de saúde, como dois os Centros de Saúde mais próximo, que são do bairro Santa Rosa e Padre Fernando de Melo. Os moradores relatam que recebem frequentemente visitas dos agentes comunitários de saúde dos respectivos postos. E acordo com o relato dos moradores - a Vila da Paz não tem Centro de Referência a Assistência Social (CRAS) o que dificulta muito o acesso deles a serviços vinculados a essa área. Observamos que há muitos moradores que tem direito à aposentadoria e a outros benefícios, porém não tem acesso à informação de como conseguir acessá-los.

Sobre o acesso a rede de comércio local - os moradores relatam a existência de supermercados próximo nas redondezas, como os supermercados EPA e BH que ficam localizados na região do Jaraguá e que alguns moradores costumam frequentar. A vila também possui pequenos comércios, como restaurantes, bares e em supermercado conhecido como JUQUITA que é o ponto comercial de maior referência para os moradores da Paz.

Em relação às opções de lazer os moradores relatam que gostam muito de ir passear em Parques ecológicos próximos à Vila, também costumam ir ao Minas Shopping, que é o shopping mais próximo do local onde moram e ao Parque Municipal, que fica localizado no centro da cidade de Belo Horizonte.

Sobre a dinâmica de participação dos moradores na Vila relatam que estão vinculados a Associação Comunitária da Vila, ao CMAR e também a grupos religiosos. Os vínculos estabelecidos são fortes entre os vizinhos e membros da família. Um aspecto interessante que diz respeito da relação entre os moradores e o lugar- é o fato de afirmarem que gostam muito do local, apesar da difícil infraestrutura que tem, e revelam também uma indignação com a situação de moradia na qual vivem ao tempo que tem esperado para saber sobre os processos de remoção e reassentamento, e relatam que já vivenciaram algum tipo de preconceito por morar na Vila, seja no trabalho ou em outros ambientes sociais que frequentam. 
Notamos que esses preconceitos sociais que trazem como efeito discursos criminalizantes sobre os moradores da Paz, tem uma função política imposta pelos setores dominantes às favelas, a qual é construir uma rede de obstáculo do acesso desses moradores aos espaços públicos. Para nós, esses discursos estão a favor de um projeto conservador de cidade, que representa aquilo que LEFEBVRE (1969) intitulou de destruição da urbanidade, que seria a restrição dos espaços de convívio e encontro, em que as diferenças se confrontam. Reforçando a lógica de que certos atores sociais não podem frequentar determinados espaços, o que dificulta o exercício da cidadania. Os discursos criminalizantes contribuem para que os moradores das ocupações se tornem cada vez mais distantes da cidade e para que o poder público justifique suas práticas remocionistas.

Todavia, o discurso criminalizante, produz também o movimento de questionar a lógica da cidade produzindo efeitos paradoxais, e fazendo emergir uma cidade que vai muito para além do direito à água e do esgoto, destacada como pauta de luta para os moradores das ocupações e da Vila da Paz, que querem apropriar da cidade como um todo, do direito a arte, da cultura, aos espaços existentes nela. Movimentos de (re) existência que trazem aos moradores da favela o direito de reconhecimento e de ampliação da luta pelo acesso a cidade.

Sob o olhar dos moradores - o lugar Vila da Paz pode ser compreendido como uma construção social que foi fundamentada entre relações sociais, no cotidiano dos moradores, nos conflitos existentes e nas estratégias de cooperação. Um conflito que marca a dinâmica da Vila da Paz é o esgoto a céu aberto, o presente tráfico de drogas e também o número de casas que foram demolidas ao longo do processo de remoção.

Segundo os moradores estão sempre em constante organização para elaboração de ofícios para que a COPASA possa arrumar o esgoto. Sobre o tráfico de drogas, relatam que não há como controlar, pois, muitos carros que fazem o retorno na Vila da Paz contribuem para a manutenção do mesmo. As casas demolidas também incomodam muitos os moradores - já deixam o vazio de quem não está mais lá. Eles têm buscado, por meio da arte (re) ocupar os espaços:

\section{Fotoetnografia de Campo: NÃO vendo está casa - (Re) ocupo!}




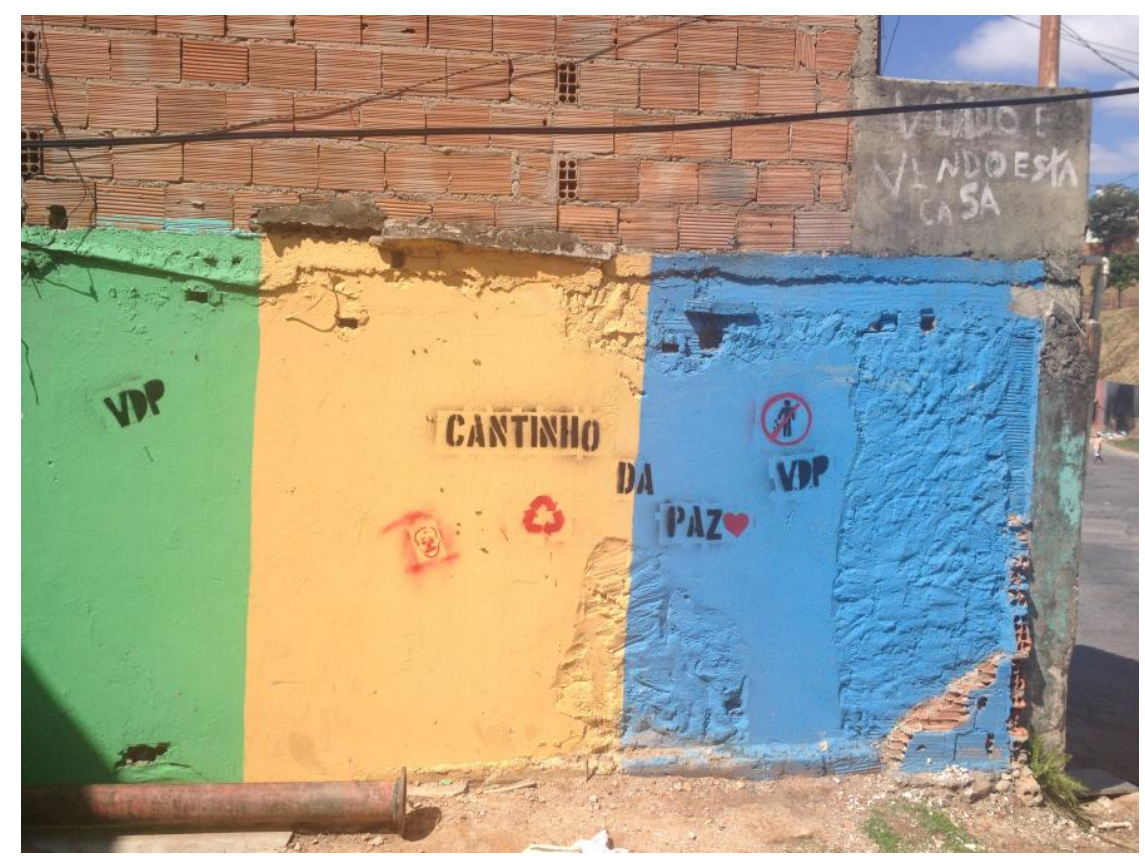

Os moradores da Paz em seus circuitos de resistência sobre a Vila, falam muito sobre a comunidade que foi ali construída. E compreendemos como comunidade um lugar de moradia e convivência afetiva e efetiva entre os moradores, que estabelecem laços de pertencimento, vivenciam dificuldades, paradoxos, problemas sociais e cultura. (GOís, 2005). A comunidade Vila da Paz não é um lugar homogêneo, mas marcado por suas diferenças, como por exemplo, entre pessoas que querem sair e querem ficar, pessoas marcadas por suas diferenças e são esses aspectos que tornam a Vila da Paz uma experiência de comunidade, e os permitem estabelecer laços de confiança e perceberem que não estão sozinhos diante das problemáticas vivenciadas, como afirmado por eles.

\section{MOVIMENTOS SOCIAIS: NOTAS SOBRE LUTAS PELA CIDADE}

Consideramos que essas (re) existências dos moradores da Paz possuem forte relação com lutas maiores e organizadas na cidade. Os movimentos sociais na cidade de Belo Horizonte emergiram com a sua fundação, já que a cidade planejada teve que aprender a conviver em seus espaços com as favelas - e um jeito de tentar afastá-las foi por meio das políticas remocionistas. Até a década 1990 os movimentos sociais existentes na cidade tiveram como objetivo pensar nas pautas do trabalho e do sindicato, devido ao grande número de operários que foram contratados para a construção da cidade. A partir de 1996, os movimentos sociais existentes começaram a 
pautar em sua agenda política de luta a reivindicação dos direitos das mulheres, dos negros e das associações de bairro (LE VEN E NEVES, 1996).

Na década de 1980, a União dos trabalhadores da Periferia (UTP) e Associações Comunitárias de Minas Gerais (FACEMG) tiveram um papel importante na permanência das famílias em processo de remoção promovidas pela Prefeitura da cidade. Outro importante movimento que trabalhou nas reivindições das moradias populares foi a Federação das Associações de Bairros Vilas e Favelas de Belo Horizonte (FAMOBH) que fora criada em 1983. Podemos dizer que a década de 1990, Belo Horizonte teve forte presença da sociedade civil e dos movimentos sociais nas esferas institucionais de luta pela moradia.

Outro movimento também importante no âmbito da cidade de Belo Horizonte foi o Grito dos Excluídos que aconteceu no dia 07 de setembro de 1995, o qual se constitui como uma mobilização de vários movimentos sociais distintos para questionar o neoliberalismo vigente (ARAÚJO E MELLO, 2012); Além desse movimentos vários outros importantes surgiram no bojo da cidade para questionar o jeito de ser cidadão prevalecente, e como forma de ocupar a cidade, como por exemplo, a Praia da Estação ${ }^{5}$, Fora Lacerda, Tarifa Zero COPAC (Comitê Popular dos Atingidos pela Copa), Fica Fícus, Duelo de MC's, Salve Santa Tereza, Lagoinha Viva, Carnaval de Rua, Assembleia Popular Horizontal, Espaço Comum Luiz Estrela, Salve a Mata do Planalto, Parque Jardim América, dentre outros que colocam como pauta a opressão vivida pelos excluídos na cidade e seus direitos de ocupá-la:

isso significa que o desejo de mudança, de um novo modelo de sociedade,
não tem como alvo apenas o aparato do Estado, não há apenas uma única
forma de transformação social. Assim como também não é possível dizer de
um projeto único de sociedade, mas de atores sociais diversos reivindicando
projetos distintos. (...) Muitas das reivindicações levadas às ruas expressam a
necessidade, inclusive, de ressignificação de questões que extrapolam essas
esferas [do setor industrial e da forma de organização do sistema político da
sociedade]. Isso não significa que os conflitos relativos ao confronto capital X
trabalho não se fazem mais presentes, mas que até os conflitos daí oriundos
são experimentados sob novas formas e são expressos pelos trabalhadores
de maneiras também distintas (ARAÚJO; MELLO, 2012, p.178-179). Dentre as diversas pautas e movimentos em prol de uma cidade mais justa, elencamos aqui o Movimento de Trabalhadores desempregados que teve forte influência sobre as linhas de resistência dos moradores da Vila da Paz, assim como outros que não mencionaremos aqui, mas que fortaleceram essas linhas de forma indireta ou direta. Entendemos que os movimentos sociais,

\footnotetext{
${ }^{5}$ Movimento criado em janeiro de 2010 para questionar a ocupação dos espaços públicos vigentes no governo do Prefeito Márcio Lacerda
} 
mesmo que em suas pautas diferentes, estão interconectados em si e compõe o circuito de resistência e reinvenção dos espaços da cidade.

O Movimento de trabalhadores (as) desempregados (as) (MTD) ${ }^{6}$ se caracteriza como uma organização popular de trabalhadores e trabalhadoras e que desenvolvem ações voltadas para fortalecimento comunitário para geração de renda e trabalho, é um movimento social que luta pelos direitos imediatos do povo, como afirma um dos participantes em conversas sobre a presente pesquisa, e a moradia tem sido uma pauta de luta deste movimento, que desenvolveu ações na Vila da Paz no ano de 2013.

Segundo relatos do MTD eles chegam à Vila a pedido da Associação de Moradores do Anel Rodoviário para auxiliar os moradores na redação de um ofício para dizer sobre o assédio moral que as famílias em processo de remoção estavam vivenciando com a Companhia Urbanizadora de Belo Horizonte (URBEL). Alguns aspectos que o MTD realça sobre o processo de remoção das famílias da Vila da Paz é a situação de insegurança e instabilidade em que vivem essas famílias sobre o fato de serem removidas em situação que tem se arrastado há alguns anos.

Os participantes dos movimentos relatam que auxiliaram os moradores da Vila da Paz desde início da remoção - quando o agente executor da obra era a URBEL. A rede de colaboração entre a Vila da Paz e o MTD surgiu quando os moradores da Paz indignados com a forma com que as remoções estavam sendo realizadas pela URBEL decidiram recorrer à justiça e para isso pediram apoio do movimento para que os auxiliassem na construção de um ofício a ser enviado em protesto contra a remoção. Atualmente dialogam com os moradores da Vila, mas relatam estar um pouco afastados da pauta de luta dos moradores da Paz devido às agendas apertadas, e outras prioridades. Mesmo de longe, afirmam acompanhar todo o movimento de desocupação do anel e não concordam com a maneira arbitrária de como tudo tem sido feito.

Vale destacar que uma grande pauta de luta e linha de resistência dos movimentos sociais está na defesa do termo ocupação em contraposição a terminologia invasão. De acordo com os atores sociais presentes nos movimentos, ocupação é a forma mais legitima de defender quem luta por direito à cidade, já que é carregado de noção política:

A ação política das ocupações tem como uma de suas motivações, justamente, o processo de institucionalização dos movimentos sociais mais antigos, que os fez perder a possibilidade de pressão sobre o poder público para a realização de políticas habitacionais. (LOURENÇO, 2014, p.29)

\footnotetext{
${ }^{6}$ Ver mais no blog do movimento em: https://mtdrio.wordpress.com/quem-somos/
} 
Sendo assim, os movimentos sociais são atores essenciais para compreendermos a dinâmica de luta pelo direito à moradia, direito à cidade, o que inclui como pauta de reivindicação: o acesso às ruas, a garantia de mobilidade, o acesso aos serviços urbanos, à necessidade do espaço público como um local de produção de cidadania, dentre outros aspectos fundamentais de uma luta por uma cidade mais justa.

\section{O DISCURSO JURÍDICO: ANÁLISES SOBRE UMA POLÍTICA URBANA PARA HIGIENIZAÇÃO}

Com as etnografias na Vila da Paz e estudos documentais sobre a Política Urbana de Belo Horizonte notamos que os discursos legais sobre a remoção legitimam a política higienista sobre a cidade. No Manifesto intitulado "Vila Viva ou Vila Morta" elaborado por movimentos sociais e entidades, vários são os elementos evidenciados sobre as práticas remocionistas presentes na Política Urbana de Belo Horizonte, como por exemplo, a quebra de laços sociais, indenizações muito baixas as famílias que são removidas, especulação imobiliária, dentre outros aspectos que exigem uma reinvenção da política Urbana em Belo Horizonte.

No caso da Vila da Paz, em âmbito institucional o órgão responsável por fazer a remoção das famílias até 2013 foi a URBEL, o que resultou uma relação conturbada com as famílias removidas, devido à falta de resposta sobre a data da saída, e também das remoções forçadas que levaram a população da vila da paz, ocuparem novamente o local. No ano de 2014 com o surgimento do Programa de Conciliação para Remoção e Reassentamento Humanizado do anel rodoviário e BR 381 e com a justificativa dos grandes números de acidente ao longo do anel foi estabelecida uma parceria entre Justiça Federal e Instituto Rondon para remoção das famílias moradoras do anel rodoviário. A proposta de remoção criada tinha embasamentos na conciliação

\footnotetext{
${ }^{7}$ Os movimentos que assinaram esse manifesto são: Associação Comunitária dos Moradores do Novo Lajedo; Associação e Núcleo de Moradia da Vila Santa Rita e Adjacências; Associação Mineira da Providência; Brigadas Populares; Coordenação Nacional de Lutas; Conselho Comunitário Assistencial e Social da Vila Marçola; Escola de Samba Cidade Jardim; Federação das Associações de Moradores de Belo Horizonte (FAMOB); Graal BH; Grupo de Amigos e Familiares de Pessoas em Privação de Liberdade; Hip Hop Gerais; Grupo de Teatro do Oprimido Levante; Movimento Nacional de Luta Pela Moradia (MNLM); Movimento Nacional de População de Rua (MNPR); Movimento dos Sem Universidade (MSU); Movimento dos Trabalhadores Desempregados (MTD); Núcleo Geração Trabalho e Renda; Núcleo de Sem Casa do Conjunto Santa Maria e Adjacências; Ocupação Camilo Torres; Ocupação Navantino Alves; Rede Popular Solidária (RPS); Sistema Caracol de Rádio; e TV Comunitária. Podemos perceber que há uma diversidade muito grande de movimentos, com agendas distintas. Mas podemos perceber que há uma predominância das associações comunitárias de bairros e regiões.
} 
entre justiça, moradores da Vila da Paz e demais vilas, com a garantia dos direitos sociais dos moradores e acompanhamento social dos mesmos.

De acordo com RANCIÉRE (1996) vivemos em um paradoxo em que no campo das ciências humanas e sociais há prevalência de um discurso que glorifica o discurso do sujeito que age que discute que contrata, todavia não há muitas pautas políticas que são permeáveis de debate. Neste sentido, o autor chama de dissenso tudo aquilo que implica o estudo sobre a diferença e o conflito, em suas formas (aquilo que nomeamos como antagonismo social, conflito de opiniões, diversidade das culturas, dentre outros). Vale a pena destacar que o dissenso não deve ser entendido como diferença de sentimentos, mas sim como um mundo comum que é instituído, é torna-se comum, pelas suas próprias divisões.

No caso dos programas de remoção e reassentamento das famílias da Vila da Paz, moradoras do Anel rodoviário, o dissenso está no que é o morar. O programa responsável pela remoção e reassentamento das famílias, juntamente com a Justiça Federal oferece aos moradores três alternativas para saírem do local em que moram: uma primeira que é a venda da casa, que permite o morador receber o dinheiro e comprar a casa em outro local, alternativa oferecida é ir para os condôminos oferecidos pelo programa e a terceira alternativa é que o morador aguarde no aluguel social até que possa "decidir" por uma das opções.

Todavia, o dissenso anunciado por RANCIÉRE (1996 a) sempre esteve presente entre as formas de pensar o que é morar para os moradores da Vila. O que os moradores relatam é que o trabalho do Programa é mais dialogal do que o da URBEL, todavia a imposição de ter que sair continua, e o significado do que é o morar para eles não é algo contemplado. Os moradores da Vila da Paz, não querem sair do local onde estão, mas também não concordam com as condições indignas que em que vivem, no sentido de não terem água tratada, luz, dos problemas com o esgoto serem recorrentes, não se sentem bem com a quantidade de acidentes que acontece, porém não são felizes com as possibilidades que the são ofertadas como possibilidade do morar, e a partir disso criam lógicas de resistência para ocupar a Vila, como retornar à Vila, nas audiências públicas os moradores fazem manifestações contra as remoções arbitrárias, as decisões no que tange as remoções e reassentamentos são tomadas em conjunto entre moradores da Vila e o CMAR.

Ao analisarmos os discursos acima, notamos a urgente necessidade de uma reinvenção da Política de Habitacional em Belo Horizonte. É muito preocupante o modelo condomínio que prevalece na cidade, já que esta forma de morar não contempla o público com menor renda, 
menor escolaridade, que depende de programa de transferência de renda. Outro aspecto, é que o sistema condominial gera novas taxas associadas às despesas de moradia, conforme realça nota Pública Rede Cidade e Moradia. Quando falamos da reinvenção estamos dizendo sobre a maior necessidade de diálogo com os moradores e do reconhecimento e respeito às demandas dos mesmos.

No caso da Política Habitacional de Belo Horizonte, como vimos no tópico anterior, a Prefeitura por meio da URBEL que estabelece parcerias com construtoras tem desenvolvido tipologias sobre o morar de forma rígida e homogênea, que não contempla o público diverso. Geralmente parte do pressuposto que o morar se reduz a um apartamento que atende os padrões da classe média, o que desagrega as pessoas que vão morar nesses estabelecimentos. De acordo com SANTOS JUNIOR (2008), a segregação espacial nas cidades (efeito da desigualdade) é fator determinante para a segregação da participação, fragilização do tecido associativo e, finalmente, para a "repartição do espaço político brasileiro entre hipercidadãos e subcidadãos" (SANTOS JUNIOR, 2008, p. 150).

Sendo assim, no caso da Vila da Paz, são vários os relatos dos moradores que foram removidos, os quais se encontram em aluguel social e reclamam do atraso do mesmo. Essa inflexibilidade da política de habitação obedece a um projeto modernista sobre o morar. No final do ano de 2016, o programa de conciliação foi destituído do processo de remoção das famílias do anel e a ideia é que esse projeto volte novamente para a URBEL. A grande questão é que não há alteração nas possibilidades de moradia que são oferecidas a população, gerando uma séria de conflitos sociais e políticos.

Um dos problemas que são acentuados na Vila da Paz é a forte presença do tráfico de drogas, além dos conflitos internos a luta pela moradia. Contudo, o que a Vila da Paz reivindica no seu cotidiano é que o morar vai muito além da conquista de uma casa ou apartamento, além de que a história dos moradores da Vila da Paz, com suas pautas, nos faz pensar sobre o modelo excludente que mantém a política habitacional em Belo Horizonte.

Sobre as re (existências) dos moradores frente às situações associadas às remoções e condições de vida narradas acima - notamos movimentos dos mesmos no sentido de questionar o retrocesso - referente à participação dos moradores sobre os processos decisórios que envolvem a remoção e o reassentamento.

Observamos também que as lideranças presentes na Vila da Paz têm participado de conselhos e movimentos sociais como expressão de luta e ativismo frente o direito à moradia digna 
e condições de habitação mais justas nos lugares onde ocupam. Como afirma HARVEY (2013, p. 1), "o direito à cidade é [...] um direito de mudar a nós mesmos, mudando a cidade". Além disso, é um direito coletivo, e não individual [...] e é nesses coletivos que os moradores têm (re) existido.

\section{CONSIDERAÇÕES FINAIS: CIRCUITOS DE RESISTÊNCIA, DESOBEDIÊNCIA E LUTA PELO DIREITO À CIDADE.}

“Numa vasta extensão. Onde não há plantação. Nem ninguém morando lá. Cada pobre que passa por ali Só pensa em construir seu lar. E quando o primeiro começa Os outros depressa procuram marcar Seu pedacinho de terra pra morar. E assim a região sofre modificação Fica sendo chamada de a nova aquarela E é aí que o lugar Então passa a se chamar favela" (Música Favela de Jorginho Pessanha e Padeirinho).

Concordamos com Latour quando ele diz que "estudar é sempre fazer política no sentido de reunir ou compor aquilo de que é feito o mundo comum" (LATOUR, 2012, p.364) e ao longo desta pesquisa observamos que pensar sobre o Direito de morar nos convida a lançar lentes analíticas ampliadas sobre o que é a cidade, e como essa temática tem sido estudada ao longo da história, compor lentes sobre os dissensos estabelecidos sobre o morar entre os moradores da Vila da Paz e a Política Urbana de Belo Horizonte.

Compreendemos a cidade como um dispositivo revelador das lógicas de opressão e manutenção de preconceitos de populações que estão em situação mais desfavorecidas. A cidade pode ser compreendida assim como um projeto de disciplinar o espaço e as pessoas. (FOUCAULT, 1979).

Notamos que a regularização fundiária é apontada pela literatura nos estudos sobre o Direito à Moradia, como um dos principais elementos para a garantia de permanência dos moradores nas ocupações, e mais do que a permanência dos mesmos, é preciso pensar sobre as condições precárias de vida que esses moradores têm sobrevivido, e como tem feito para reinventar o morar.

O objeto de análise dessa pesquisa consistiu em apresentar as teias do significado do morar, enquanto possibilidades de (re) existir e direito de escolher, para os moradores, visto que, a investigação de uma resposta possível se encontra na voz dos diversos atores participantes desta rede de ações.

O que observamos no caso da Política Urbana de Belo Horizonte é que ao invés de se incluir os moradores nos processos decisórios- o que seria um grande passo tem-se gradativamente colocado as decisões sobre habitação por meio de Conselhos de Políticas Públicas, 
em que quase não há espaços para a participação mais direta de quem é atingido. O que presenciamos, é a inclusão da palavra participação em todo o processo de remoção e reassentamento, sem verdadeiramente incluir quem vivencia o processo. Neste sentido, surge a seguinte pergunta, para onde vai Belo Horizonte, quando a temática é remoções?

A própria filosofia da política Urbana de remoção na cidade de Belo Horizonte tem como foco a remoção de pessoas sem se perguntar muito sobre como ficam as condições de vida da população. Este também é um imperativo bem presente na remoção da Vila da Paz. Vale destacar que a situação das remoções que estão presentes na Política Urbana em Belo Horizonte - não se constitui como fato isolado. Desde o anuncio que o país seria sede da Copa do Mundo, várias cidades brasileiras intensificaram remoções forçadas. O que percebemos no caso da cidade de Belo Horizonte, como apontam FERNANDES E PEREIRA (2010) é a presença de dois movimentos, sendo um primeiro a precariedade da regularização fundiária, e um segundo a insegurança das famílias removidas em relação à permanência no local e a posse de terra, elementos bem presentes nas narrativas dos moradores da Paz quando falam sobre os anseios sobre a remoção.

Sendo assim, podemos tomar como base e fazer uma analogia com um estudo que Foucault fez sobre a implantação das estradas de ferro na França. Segundo Foucault (1982) os gerenciadores do processo colocaram como hipótese que a instalação dessas estradas agenciaria a familiaridade entre as pessoas, entretanto isso não aconteceu, pelo contrário, o caminho de ferro tornou a guerra bem mais fácil. E a suposta remoção humanizada, o que possibilitou de efeitos na vida dos moradores?

Para FOUCAULT (1982) as cidades devem ser pensadas a partir das relações entre o exercício do poder político e o espaço do território, e as relações completamente novas que são advindas dessa relação espaço-poder. Os princípios técnicos do espaço são aqueles que estão em prol do chamado desenvolvimento do território:

Não me parece possível dizer que uma coisa é da ordem da «libertação» e outra é da ordem da "opressão». Há certo número de coisas que podem dizer-se, com alguma certeza, sobre um campo de concentração no sentido de não ser um instrumento de libertação, mas deve ter-se em conta o facto geralmente ignorado - que, excetuando a tortura e a execução que tornam toda a resistência impossível, por muito terrível que seja um dado sistema, ficam sempre possibilidades de resistência, desobediência e de constituição de grupos de oposição... A liberdade é uma prática. Assim, haverá, de facto, certo número de projetos que procuram modificar alguns constrangimentos, flexibilizá-los ou mesmo quebrá-los, mas nenhum desses projetos podem, simplesmente, pela sua natureza, assegurar que as pessoas sejam automaticamente livres, que isso possa ser estabelecido pelo projeto em si mesmo.

Revista de Direito da Cidade, vol. 09, no 1. ISSN 2317-7721 pp. 233-275 
Essas remoções que descortinam a segregação socioespacial presente na cidade em que temos uma demarcação na geografia da cidade, daqueles que são considerados abastados, e dos que vivem em situação de insalubridade. Como afirma ROSEN (1994) os modelos de segregação sociespacial representam a inscrição da desigualdade social no território e na história da cidade.

Outro aspecto importante que podemos concluir com essa pesquisa é que além das coisas, e dos lugares, as pessoas pobres a serem removidas se constituem como um campo de intervenção e são tomados como objetos da suposta "sanidade urbana" e da "ordem pública" (FOUCAULT, 1979). Notamos que o discurso presente na história de remoção e reassentamento das ruas e ocupações de Belo Horizonte não leva em consideração o que é o morar para as pessoas que residem na Vila da Paz. As possibilidades de decidir que são apresentadas aos moradores, já vem em uma cartela de três opções definidas por uma instância muito maior.

O que percebemos nos relatos etnográficos da Vila da Paz - é que a ela emerge na contramão, como movimento livre de criação de outra cidade, ainda que em terrenos precários, e com condições sociopolíticas mais frágeis e até mesmo violentas. Gostaríamos de reafirmar assim, que o movimento de resistência da Vila da Paz deve ser reconhecido para além dos imperativos que associadas à vila - como lugar de ocupação irregular, ou de quantidades de acidentes e problemas infraestruturais. Não estamos negando esses problemas, todavia a Vila existe para além deles.

Observamos a presença de um discurso que tenta criminalizar os moradores da Vila da Paz, e os colocar no lugar da não fala. Os moradores não podem falar e quando tentam, não encontram meios de serem ouvidos, pois a possibilidade de o "novo morar" já lhes foi dito. O que nos convoca ao diálogo com SPIVAK (2010) quando a autora coloca que ao subalterno são colocadas questões políticas e sociais, que em sua grande maioria relaciona-se com a experiência de opressão e invisibilidade diante de interesses hegemônicos direcionados a determinados grupos sociais.

O que notamos é que - em paralelo a tentativa de hegemonizar o morar presente nas Políticas de Habitação de Belo Horizonte e seu movimento higienista, como vimos anteriormente, há uma forte presença do movimento de negação-criação (HOLOWAY, 2013) de o novo morar que vem emergindo e este movimento está presente no modo como a Vila da Paz está enfrentando os processos de remoção, na luta pelo acesso ao Direito à Cidade, por meio das desobediências, e nas lutas nos coletivos.

Um aspecto importante observado durante a pesquisa é que o morar - nas narrativas dos moradores da Vila da Paz transcende a questão de ter uma casa. O morar na história dos 
moradores da Vila aciona uma teia de significados e resistência que evoca a rede comunitária existente entre os moradores, os lugares que vão juntos, os pontos em que fazem o supermercado, compram roupas e se divertem.

Reconhecemos assim, componentes simbólicos e imaginários na constituição do morar, e também da cidade. E são esses componentes que esta pesquisa buscou visibilizar, na Vila da Paz, e na cidade de Belo Horizonte, nas representações que temos da cidade dali, e da cidade de cá.

\section{REFERÊNCIAS BIBLIOGRÁFICAS}

ABREU, Maurício de Almeida. A cidade da geografia no Brasil: percursos, crises, superações. In: OLIVEIRA, Lúcia Lippi. CIDADE: história e desafios. Rio de Janeiro: Ed. Fundação Getúlio Vargas, 2002.

ACHUTTI, Luiz Eduardo Robinson. Fotoetnografia: um estudo de Antropologia Visual sobre cotidiano, lixo e trabalho. Porto Alegre: Tomo 1997.

ARAÚJO, Wânia Maria de e MELLO, Ediméia Maria Ribeiro de. Movimentos Sociais: reflexões sobre o século XX e as conexões possíveis com as experiências do século XXI. In: MACHADO, Lucília Regina de Souza; AFONSO, Maria Lúcia Miranda. Gestão Social, Educação e Desenvolvimento Local. Belo Horizonte: Autêntica Editora, 2012

AMARAL, Tarsila do. Segunda Classe, São Paulo, 1923.

ANDRADE, Mário de. O movimento modernista. Aspectos da literatura brasileira. São Paulo: Livraria Martins/INL, 1978.

ALVAREZ, Marisol. Ressignificações urbanas de fin de siglo. Entelequia: Cuaderno de Comunicación, Montevideo, n.5. Dec.1995.

ASSIS, Eleonora Sad. O plano de Belo Horizonte em fins de século XIX: O enunciado e o visível. São Paulo: FAU/USP, 1995.

BARTHES, Roland. A câmara clara. Rio de Janeiro: Nova Fronteira, 1984.

O óbvio e o obtuso. Rio de Janeiro: Nova Fronteira, 1990.

BARROS, José Márcio. Cultura e Comunicação: Nas avenidas de contorno em Belo Horizonte e La Plata. Editora PUCMINAS, Belo Horizonte, 2005.

BORDIEU, Pierre. Choses dites. Paris: Les Éditions de Minuit, 1987

CARRETEIRO, Teresa Cristina. Sofrimentos Sociais em Debate. Psicol. USP [online]. 2003, vol.14, n.3 [cited 2016-10-23], pp.57-72. Available from: <http://www.scielo.br/scielo.php?script=sci_arttext\&pid=S0103- 
65642003000300006\&lng=en\&nrm=iso>. ISSN 0103-6564. http://dx.doi.org/10.1590/S010365642003000300006 .

CASTELLS, M. La question urbaine. Paris: Maspero, 1977.

DAVIS, M. Planeta favela. São Paulo, Boitempo, 2006.

DURKHEIM, E. Sociologia e Ciências Sociais. In: Ciência Social e a ação. Lisboa: Bertrand, 1970

ENGELS, F. A situação da classe trabalhadora na Inglaterra. São Paulo: Global, 1985

FERNANDES, Ana; GOMES, Marco Aurélio A. de Filgueiras. História da cidade e do urbanismo no Brasil: reflexões sobre a produção recente. Cienc. Cult., São Paulo, v. 56, № 2, Apr. 2004. Available from <http://cienciaecultura.bvs.br/scielo.php?script=sci_arttext\&pid=S000967252004000200015\&lng=en\&nrm=iso>. Access on 23 Oct. 2016.

FERNANDES, E. e PEREIRA, H. D. Legalização das favelas: qual é o problema de Belo Horizonte? Planejamento e Políticas públicas, no 34, 2010.

FOUCAULT, Michel. Space, Knowledge and Power. Entrevista a Paul Rabinow. Skyline. 1982. In. HAYS, Michael. Org. Architecture Theory since 1968. The MIT Press.

Vigiar e punir: a história da violência nas prisões. Traduzido por Raquel Ramalhete. 2. Ed. Petrópolis/RJ: Vozes, 1999.

Segurança, território e população. Traduzido por Eduardo Brandão. São Paulo: Martins Fontes, 2008.

A política de saúde no século XVIII. Traduzido por Roberto Machado. In: MACHADO, R. (Org.) Microfísica do poder. Rio de Janeiro: Graal, 1979d, p. 193-207.

Nietzsche, a genealogia e a história. Traduzido por Roberto Machado. In: MACHADO, R. $\overline{(O r g .)}$ Microfísica do poder. Rio de Janeiro: Graal, 1979c.

FUNDAÇÃO JOÃO PINHEIRO. (2014). Nota Técnica 1: Déficit Habitacional no Brasil 2011-2012 Resultados Preliminares. Belo Horizonte, FJP. Disponível em: http://www.fjp.mg.gov.br/index.php/docman/cei/deficit-habitacional/363-deficit-nota-tecnica-dh2012/file. Acesso em: jun 2014.

GEERTZ, Clifford. Uma descrição densa: por uma teoria interpretativa da cultura. In: A interpretativa das culturas. Rio de Janeiro: Zahar, 1978.

GORELIK, Adrián. A produção da "cidade latino-americana". Tempo Soc., São Paulo, v. 17, n. 1. June 2005. Available from <http://www.scielo.br/scielo.php?script=sci_arttext\&pid=S010320702005000100005\&lng=en\&nrm=iso>. Access on 05 nov. 2016. http://dx.doi.org/10.1590/S0103-20702005000100005

GONÇALVES, M. F. Processo de urbanização no Brasil: delimitação de campo de pesquisa. Espaço e Debate, n. 28, 1989, p.67-79,

GÓIS, C. W. L. (2005). Atividade e consciência. Fortaleza: Instituto Paulo Freire 
GRAFMEYER, Y.; JOSEPH, I. (Org.) L’École de Chicago. Paris: Éditions du Champ Urbain,1979.

HARVEY, D. O direito à cidade. Revista Piauí n. 82. Disponível em: http://revistapiaui.estadao.com.br/edicao-82/tribuna-livre-da-luta-de-classes/o-direito-a cidade. Acesso em 18 de dezembro de 2016.

HOLLOWAY, J. Fissurar o capitalismo. São Paulo, Publisher Brasil. (Originalmente publicado em inglês em 2010, como Crack capitalism), 2013.

JULIÃO, Letícia. Belo Horizonte: itinerários da cidade moderna. IN: DUTRA, Eliana F. (Org); BH Horizontes históricos. Belo Horizonte. C/Artes, 1996.

MARICATO, E. "Um mundo dominado pelas favelas". In: DAVIS, M. Planeta Favela; São Paulo, Boitempo, 2005.

"É a questão urbana, estúpido! " In: MARICATO, E. et al. (Org.) Cidades rebeldes; São Paulo, Boitempo/Carta Maior, 2013.

MAGALHÃES, Beatriz de A.; ANDRADE, Rodrigo F. Belo Horizonte: um espaço para a República. Belo Horizonte: UFMG, 1989.

MAGNANI, José Guilherme. TORRES, Lilian de Lucca. Na métrolole: Textos de antropologia urbana. São Paulo. Edusp, 1996.

Manifesto "Programa Vila Viva ou Vila Morta" disponível em: <http://brasil.indymedia.org/media/2008/10//429698.pdf> Acessado em 17/12/2016

MARX, K. O Capital. Rio de Janeiro: Civilização Brasileira, 1984.

MARK, Karl, and ENGELS, Friedrich Manifesto comunista. Boitempo Editorial, 2015.

MELLO, Ciro Bandeira de. A noiva do trabalho: uma capital para a República. In: DUTRA, Eliane F. (Org.) BH horizontes históricos. Belo Horizonte: C/Artes, 1996.

MINAYO, M.C.S. O desafio do conhecimento. São Paulo/Rio de Janeiro: Hucitec/Abrasco, 1992.

NUN, J. Marginalidad y otras cuestiones. Revista Latinoamericana de Ciencias Sociales, no 4, 1972

LATOUR, Bruno. Reagregando o Social: uma introdução à teoria do ator-rede. Salvador-Bauru: EDUFBA-EDUSC, 2012

LEDRUT, R. L' espace en question. Paris: Anthropos, 1976.

LEFEBVRE, Henri. O direito à cidade. Documentos: São Paulo, 1969

La vie sociale dans la ville. In: Du rural à I'urbain. Paris: Anthropos, 1970.

LE VEN, Michel Marie; NEVES, Magda de Almeida. Belo Horizonte: trabalho e sindicato, cidade e cidadania (1897-1990). In: DULCI, Otávio; NEVES, Magda de Almeida (Orgs.). Belo Horizonte: poder, política e movimentos sociais. Belo Horizonte: C/Arte, 1996, p. 75-106. 
LIBÂNIO, Clarice de Assis. O fim das favelas? Planejamento, participação e remoção de famílias em Belo Horizonte. Cadernos Metrópole, 18(37). https://dx.doi.org/10.1590/2236-9996.2016-3707, 2016.

LOPES, E. O Projeto Linha Verde e a remoção de cinco vilas: um estudo de caso da prática do desfavelamento de novo tipo no espaço urbano de Belo Horizonte. Dissertação de Mestrado. Belo Horizonte, Universidade Federal de Minas Gerais. Belo Horizonte. Disponível em: http://www.bibliotecadigital.ufmg.br/dspace/bitstream/handle/1843/MPBB8AWDPV/disserta_o_ erika_,2010. Acesso em 23 de dezembro de 2016.

LOURENÇO, Tiago Castelo Branco. Cidade Ocupada. 2014. Dissertação (Mestrado) - Universidade Federal de Minas Gerais, Núcleo de Pós-graduação em Arquitetura e Urbanismo. Belo Horizonte, 2014

PARK, R. Um roteiro de investigação sobre a cidade. In: VELHO, G. (Org.). O fenômeno urbano. Rio de Janeiro: Zahar, 1987

PUSSETTI, Chiara e BRAZZABENI, Micol. Sofrimento social: idiomas da exclusão e políticas do assistencialismo. Revista do Centro de Rede de Investigação em Antropologia. Vol. 15 (3), pág., 467-478, 2011. Disponível em: https://etnografica.revues.org/1036

PROUST, Françoise. The line of resistance. Translated by Penelope Deutscher. In: Hypatia, vol.15, Issue 4, 2000.

QUIJANO, A. Notas sobre o conceito de marginalidade. In: PEREIRA, L. (Org.). Populações marginais. São Paulo: Duas Cidades, 1978.p.11-72

RANCIÈRE, Jacques. O dissenso. In: A crise da razão. Organizador: Adauto Novaes (Org.). São Paulo: Companhia das Letras,1996. Tradução de Paulo Neves.

(1996a). O desentendimento - política e filosofia. São Paulo, Ed. 34

Relatório especial do conselho de direitos humanos da ONU à moradia adequada: Disponível em: $<$ http://direitoamoradia.org/pt/noticias/blog/megaeventos/belohorizonte/2010/09/15/copa-2014em-bh-2-600-famlias-da-rua/>.Acesso em: 18 de dezembro 2016

ROSEN, George. Uma história da saúde pública. São Paulo: Hucitec, 1994. 423p.

ROLNIK, Raquel. "Planejamento urbano nos anos 90: novas perspectivas para velhos temas." RIBEIRO, Luiz C. de Q. e SANTOS JÚNIOR, Orlando A. dos (Orgs.). Globalização, fragmentação e reforma urbana: o futuro das cidades brasileiras na crise 2 351-360, 1994;

ROLNIK, Raquel; RIBEIRO, A. C. T.; VAZ, L. F.; SILVA, M. L. P. "10 Anos do Estatuto da Cidade: Das Lutas pela Reforma Urbana às Cidades da Copa do Mundo". In: RIBEIRO, A.C.T; VAZ, L.F.; SILVA, M.L.P. (Org.). Quem planeja o território? Atores, arenas e estratégias. 1 ed. Rio de Janeiro: Letra Capital/ANPUR, 2012b, v. -, p. 87-104, 2004.

SANT'ANNA, M. J. G. A concepção de cidade em diferentes matrizes teóricas das ciências sociais. Revista Rio de Janeiro, (9), 91-99, 2003. 
SANTOS JUNIOR, O. A. "Reforma Urbana: desafios para o planejamento como práxis transformadora", In: COSTA, G. M. e MENDONÇA, J. Planejamento urbano no Brasil: trajetória e perspectivas. Belo Horizonte, Ed. C/Arte, 2008.

SIMMEL, G. A metrópole e a vida mental. In: VELHO, Otávio (Org.). O fenômeno urbano. Rio de Janeiro. Guanabara, 1987, p.11-35.

SPIVAK, Gayatri Chakravorty. Pode o subalterno falar? Belo Horizonte: Editora da UFMG, 2010.

TUAN, Yi Fu. Espaço e Lugar: a perspectiva da experiência. Trad. Lívia de Oliveira. São Paulo: Difel, 1983

VALLADARES, L.; FREIRE-MEDEIROS, B. Olhares sociológicos sobre o Brasil urbano: o Projeto UrbanData-Brasil. Texto presentado no Seminário da Fundação Getúlio Vargas, Rio de Janeiro, agosto, 2001.

WEBER, M. A origem do capitalismo moderno. In: História geral da economia. São Paulo: Mestre Jou, 1968, p.310.

WIRTH, L. O urbanismo como modo de vida. In: VELHO, G. (Org.). O fenômeno urbano. Rio de Janeiro: Zahar 1987

Trabalho enviado em 29 de dezembro de 2016.

Aceito em 20 de janeiro de 2017. 